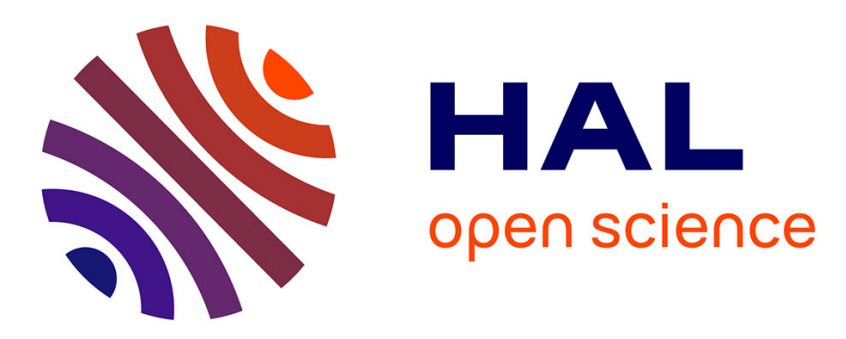

\title{
Masonic Connections and Rivalries between France and Britain
}

\author{
Pierre-Yves Beaurepaire
}

\section{To cite this version:}

Pierre-Yves Beaurepaire. Masonic Connections and Rivalries between France and Britain. Valérie Capdeville; Alain Kerhervé. British Sociability in the Long Eighteenth Century. Challenging the Anglo-French Connection, Boydell \& Brewer, pp.109-126, 2019, 9781787444904. 10.1017/9781787444904.010 . hal-03086312

\section{HAL Id: hal-03086312 \\ https://hal.science/hal-03086312}

Submitted on 11 Jan 2021

HAL is a multi-disciplinary open access archive for the deposit and dissemination of scientific research documents, whether they are published or not. The documents may come from teaching and research institutions in France or abroad, or from public or private research centers.
L'archive ouverte pluridisciplinaire HAL, est destinée au dépôt et à la diffusion de documents scientifiques de niveau recherche, publiés ou non, émanant des établissements d'enseignement et de recherche français ou étrangers, des laboratoires publics ou privés. 


\section{British Sociability in the \\ Long Eighteenth Century}




\section{Studies in the Eighteenth Century 2398-9904}

This major series from Boydell \& Brewer, published in association with the British Society for Eighteenth Century Studies, aims to bring into fruitful dialogue the different disciplines involved in all aspects of the study of the long eighteenth century (c.1660-1820). It publishes innovative volumes, singly or co-authored, on any topic in history, science, music, literature and the visual arts in any area of the world in the long eighteenth century and particularly encourages proposals that explore links among the disciplines, and which aim to develop new cross-disciplinary fields of enquiry.

Series editors: Ros Ballaster, University of Oxford, UK; Matthew Grenby, Newcastle University, UK; Robert D. Hume, Penn State University, USA; Mark Knights, University of Warwick, UK; Renaud Morieux, University of Cambridge, UK

Previously published:

Material Enlightenment: Women Writers and the Science of Mind, 1770-1830, Joanna Wharton, 2018

Celebrity Culture and the Myth of Oceania in Britain, 1770-1823, Ruth Scobie, 2019 


\title{
British Sociability in the Long Eighteenth Century
}

\author{
Challenging the \\ Anglo-French Connection \\ Edited by \\ Valérie Capdeville and Alain Kerhervé
}

THE BOYDELL PRESS 


\section{(c) Contributors 2019}

All Rights Reserved. Except as permitted under current legislation no part of this work may be photocopied, stored in a retrieval system, published, performed in public, adapted, broadcast, transmitted, recorded or reproduced in any form or by any means, without the prior permission of the copyright owner

First published 2019

The Boydell Press, Woodbridge

ISBN 9781783273591

The Boydell Press is an imprint of Boydell \& Brewer Ltd

PO Box 9, Woodbridge, Suffolk IP12 3DF, UK and of Boydell \& Brewer Inc.

668 Mt Hope Avenue, Rochester, NY 14620-2731, USA website: www.boydellandbrewer.com

A CIP catalogue record for this book is available from the British Library

The publisher has no responsibility for the continued existence or accuracy of URLs for external or third-party internet websites referred to in this book, and does not guarantee that any content on such websites is, or will remain, accurate or appropriate

This publication is printed on acid-free paper 


\section{Contents}

List of illustrations

List of contributors

ix

Foreword by Michèle Cohen

xiii

Acknowledgements

xvi

Introduction

Valérie Capdeville and Alain Kerhervé

Part 1 Emergence of new political and social practices

1 'Restoration' England and the history of sociability Brian Cowan

2 Mapping sociability on Restoration townscapes

Marie-Madeleine Martinet

3 Club sociability and the emergence of new 'sociable' practices Valérie Capdeville

4 The tea-table, women and gossip in early eighteenth-century Britain

Markman Ellis

Part 2 Competing models of sociability

'Amateurs' vs connoisseurs in French and English academies of painting Elisabeth Martichou

6 Masonic connections and rivalries between France and Britain Pierre-Yves Beaurepaire

7 Competing models of sociability: Smollett's repossession of an ailing British body Annick Cossic-Péricarpin 
8 A theory of British epistolary sociability?

Alain Kerhervé

9 Gender and the practices of polite sociability in late eighteenth-century Edinburgh

Jane Rendall

Part 3 Paradoxes of British sociability

183

10 In company and out: the public/private selves of Johnson and Boswell

Allan Ingram

11 Friendship and unsociable sociability in eighteenth-century literature

Emrys Jones

12 The anti-social convivialist: toasting and resistance to sociability

Ian Newman

13 Sociability and the Glorious Revolution: a dubious connection in Burke's philosophy Norbert Col

14 Respectability vs political agency: a dilemma for British radical societies

Rémy Duthille

Conclusion

Valérie Capdeville

Bibliography

Index 


\section{Illustrations}

Figure 1. Genealogy of the Russell family and map of associated London place names (from Georgian Cities http://www.18thc.cities.paris-sorbonne.fr)

Figure 2. A strip map by John Ogilby, Britannia (1675) 33

Figure 3. Frontispiece of John Ogilby's Britannia (1675) 34

Figure 4. Gresham College, by George Vertue (1740) 35

Figure 5. Byrsa Londinensis, vulgo The Royall Exchange of London (1644), by Wenceslaus Hollar (1607-77). (Royal Collection Trust / @ Her Majesty Queen Elizabeth II, 2018)

Figure 6. Sutton Nicholls, The Monument to the Great Fire of London, 1671-76 (c. 1754). (Courtesy of the Lewis Walpole Library, Yale University)

Figure 7. Robert Hooke, Picture Box (1694)

Figure 8. Members of the Society of Dilettanti, by William Say (printmaker, 1812-16), after Joshua Reynolds (1777-78). (Courtesy of the Lewis Walpole Library, Yale University)

Figure 9. The Tea-Table, c. 1710. (Courtesy of the Lewis Walpole Library, Yale University)

The editors, contributors and publisher are grateful to all the institutions and persons listed for permission to reproduce the materials in which they hold copyright. Every effort has been made to trace the copyright holders; apologies are offered for any omission, and the publisher will be pleased to add any necessary acknowledgement in subsequent editions. 
The publishers and editors acknowledge the generous financial support of the Université de Bretagne Occidentale 


\section{Notes on contributors}

Pierre-Yves Beaurepaire is Professor of Early Modern History at the University of Côte d'Azur (France) and an honorary fellow of the Institut Universitaire de France. He chaired the 'Centre de la Méditerranée moderne et contemporaine'. His research concerns the history of the Enlightenment in France and Europe, freemasonry, sociability and networks in the eighteenth century. He is the author of fifteen books, among which are Le Mythe de l'Europe française. Diplomatie, culture et sociabilités au temps des Lumières (Paris, 2007) ; Echec au roi. Irrespect, contestations et révoltes dans la France des Lumières (Paris, 2015). He recently edited La Communication en Europe de lâge classique au siècle des Lumières (Paris, 2014); Religious Interactions in Europe and the Mediterranean World: Coexistence and Dialogue from Twelfth to the Twentieth Centuries (London, 2017) with Katsumi Fukasawa and Benjamin Kaplan; Moving Scenes: The Circulation of Music and Theatre in Europe, 1700-1815 (Oxford, 2018) with Philippe Bourdin and Charlotta Wolff.

Valérie Capdeville is a Senior Lecturer in British History and Civilisation at the University of Paris 13 (France). She has specialised in the social and cultural history of British clubs and sociability in the eighteenth century. She is the author of L'Age d'or des clubs londoniens (1730-1784) (Paris, 2008) and she co-edited La Sociabilité en France et en GrandeBretagne au siècle des Lumières, vol. 3. Les Espaces de sociabilité (Paris, 2014) with Eric Francalanza. She is currently working on the exportation of the British club model to the American colonies (1720-70). She is the co-founder of the GIS Sociabilités/Sociability in the Long Eighteenth Century (an international Research Interest Group) and the President of its Scientific Council.

Michèle Cohen is Emeritus Professor in Humanities at Richmond American International University in London. She works on education, gender and national character. She is the author of Fashioning Masculinity: National Identity and Language in the Eighteenth Century (Abingdon, 
1996) and co-edited English masculinities 166o-180o (London, 1999) with Tim Hitchcock. More recently, she has been focusing on the education of both sexes, and has published several articles on the role of conversation in the education of males and females in social and domestic spaces. Her current project is a book on the education and fashioning of the Lady and the Gentleman in eighteenth-century England.

Norbert Col is Professor of British History and Literature at the University of Southern Brittany, Lorient (France). He has specialised in the history of ideas, mostly around Edmund Burke and Jonathan Swift. He is the author of À la Recherche du conservatisme britannique: Historiographie, britannicité, modernité (XVIIe-XVIIIe siècles) (Rennes, 2007) and co-edited La Sociabilité en France et en Grande-Bretagne au siècle des Lumières, vol. 4 : Utopie, individu et société : la sociabilité en question (Paris, 2015) with Allan Ingram.

Annick Cossic-Péricarpin is Professor of English at the University of Western Brittany, Brest (France). She is the author of Bath au XVIIIe siècle: les fastes d'une cité palladienne (Rennes, 2000) and of an annotated edition of The New Bath Guide by Christopher Anstey (Oxford, 2010). She also co-edited Spas in Britain and in France in the Eighteenth and Nineteenth Centuries (Newcastle, 2006) and is the series editor of 'Transversales' (Paris), for which she co-edited three volumes of $L a$ Sociabilité en France et en Grande-Bretagne au siècle des Lumières (vol. 1, 2012; vol. 2, 2013; vol. 5, 2016). She is the co-founder and Director of the GIS Sociabilités/Sociability in the Long Eighteenth Century (an international Research Interest Group).

Brian Cowan is an Associate Professor at McGill University (Montreal) and holds the Canada Research Chair in Early Modern British History. He studies the social and cultural history of ideas in early modern Britain and Europe. He is the author of The Social Life of Coffee: The Emergence of the British Coffeehouse (New Haven, CT, 2005) and of The State Trial of Doctor Henry Sacheverell (Chichester, 2012). He is currently working on the politics of celebrity in Britain (1650-180o).

Rémy Duthille is a Senior Lecturer in British Civilisation at the University of Bordeaux Montaigne (France). He works on political discourse in Britain in the late eighteenth century (especially Richard Price). His current research concerns political sociability, with a special focus on political drinking and toasting. He is the author of Le Discours radical en Grande-Bretagne, 1768-1789 (Oxford, 2017) and the co-editor of 'Sociabilité et convivialité en Europe et en Amérique du Nord, XVIIe-XVIIIe siècles', Lumières 21 (2013) with Jean Mondot and Cécile Révauger. 
Markman Ellis is Professor of Eighteenth-Century Studies at Queen Mary University of London. He is the author of The Politics of Sensibility (Cambridge, 1996), The History of Gothic Fiction (Edinburgh, 200o) and The Coffee-House: a Cultural History (London, 2004). He edited Eighteenth-Century Coffee House Culture (London, 2006) and Tea and the Tea-Table in Eighteenth-Century England (London, 2010). He recently co-authored Empire of Tea (London, 2014) and is now working on the sociability of science and literature in mid-eighteenth century London.

Allan Ingram is Emeritus Professor of English at the University of Northumbria. He has specialised in eighteenth-century literature and medicine, worked on Boswell and Johnson, and on topics such as melancholy, insanity and depression. He is the author of The Madhouse of Language: Writing and Reading Madness in the Eighteenth Century (Abingdon, 1992) and co-authored Cultural Constructions of Madness in Eighteenth-Century Writing (Basingstoke, 2005). He has published an edition of Jonathan Swift's Gulliver's Travels (Calgary, 2012). He also coedited the four-volume Depression and Melancholy, 166o-180o (London, 2012) with Leigh Wetherhall-Dickson, and La Sociabilité en France et en Grande-Bretagne au siècle des Lumières, vol. 4 : 'Utopie, individu et société : la sociabilité en question' (Paris, 2015) with Norbert Col.

Emrys D. Jones is Lecturer in Eighteenth-Century Literature and Culture at King's College London. He completed his Ph.D. at the University of Cambridge, his thesis examining representations of friendship in eighteenth-century political discourse. This research gave rise to his first monograph, Friendship and Allegiance in Eighteenth-Century Literature (Basingstoke, 2013). He is co-editor of the journal Literature and History. He also co-edited Intimacy and Celebrity in Eighteenth-Century Literature: Public Interiors (Basingstoke, 2018) with Victoria Joule.

Alain Kerhervé is Professor of British studies at the University of Western Brittany, Brest (France) and the current Director of research unit HCTI (Héritages et Constructions dans le Texte et l'Image). He has specialised in the theory and practice of letter-writing in eighteenth-century England. He is the author of Polite Letters: The Correspondence of Mary Delany (1700-1788) and Francis North, Lord Guilford (1704-1790) (Newcastle, 2009), of The Ladies Complete Letter-Writer (1763) (Newcastle) and of Memoirs of the Court of George III. Volume 2. Mary Delany (170o-1788) and the Court of George III (London, 2015), and co-edited La Sociabilité en France et en Grande-Bretagne au Siècle des Lumières : l'émergence d'un nouveau modèle de société, vol. 5. Sociabilités et esthétique de la marge (Paris, 2016) with Annick Cossic. He is the co-founder of the GIS Sociabilités/Sociability in the Long Eighteenth Century. 
Elisabeth Martichou is a Senior Lecturer in British Civilisation at the University of Paris 13 (France). She has specialised in art history and more particularly in art theory in eighteenth-century England. She has published several articles on Joshua Reynolds and on artistic sociability, including 'Le peintre-gentleman : un modèle de sociabilité et ses variations dans l'Angleterre du dix-huitième siècle', in Artistes, savants et amateurs: Art et Sociabilité au XVIIIe siècle (1715-1815), ed. Jessica L. Fripp, Amandine Gorse, Nathalie Manceau and Nina Struckmeyer (Paris, 2016), pp. 29-37.

Marie-Madeleine Martinet is an Honorary Professor at Sorbonne-Université (France) and the Director of research group 'Cultures, Sociétés et Technologies de l'Information'. She has specialised in historical visual culture, the aesthetics of landscape and space in English culture, and e-media. She has published several books: Art et nature en GrandeBretagne au XVIIIe siècle (Paris, 1980); Le Voyage d'Italie dans les littératures européennes (Paris, 1996) and worked extensively on digital imaging and aesthetic virtual models, which recently led to the creation of the Georgian Cities website (http://www.18thc-cities.paris-sorbonne. fr, 2014).

Ian Newman is an Assistant Professor at the University of Notre Dame (Indiana, USA). He works at the intersections of literature, song, politics and urban space across the eighteenth and nineteenth centuries in Britain and Ireland. He is co-editor with Oskar Cox Jensen and David Kennerley of Charles Dibdin and Late Georgian Culture (Oxford, 2018). He is also the author of The Romantic Tavern: Literature and Conviviality in the Age of Revolution (Cambridge, 2019).

Jane Rendall is an Honorary Fellow of the History Department and the Centre for Eighteenth Century Studies at the University of York. She has worked on the history of the Scottish Enlightenment and currently researches women's activities and writing in late eighteenth- and early nineteenth-century Britain, especially Scotland. She is the author of The Origins of Modern Feminism: Women in Britain, France, and the United States, 1780-186o (Basingstoke, 1985) and other works. She has co-edited various volumes on women's history and gender politics, including Gender, War and Politics: Transatlantic Perspectives, 1775-1830 (Basingstoke, 2010) and, most recently, The New Biographical Dictionary of Scottish Women (Edinburgh, 2018). 


\title{
Chapter 6
}

\section{Masonic connections and rivalries between France and Britain*}

\author{
Pierre-Yves Beaurepaire
}

$I^{\prime}$ N A WORLD of Freemasonry that was used to being fairly discreet and to favouring orality, we find two written documents that are worth opening this chapter with because they reveal the complex relationship that French Freemasons maintained with England, or the British Isles more broadly, during the Enlightenment. The first document was aimed at the profane Masonic population. Just after the signing of the Treaty of Versailles (1783), which put an end to the American War of Independence, the French lawyer, academic and encyclopedist Edme Beguillet, an officer of the newly opened Parisian lodge La Réunion des Etrangers, published his Discours sur l'origine, les progrès, et les révolutions de la franc-maçonnerie philosophique, contenant un plan d'association et un projet maçonnique de bienfaisance, pour l'erection d'un double monument en l'honneur de Descartes. ${ }^{1}$ It was both a plea in favour of Descartes, who was a national philosophical celebrity, ${ }^{2}$ and a violent attack on Newton and all those in France who promoted his theories: 'The Masonic commendation of Descartes will be followed by an exposition of his little-known philosophy, which has almost sunk into oblivion since Anglomania caused us to be infatuated with a foreign system.'

Note: all citations from French sources have been translated.

Discourse on the origin, progress and revolutions of philosophical Freemasonry, including an association plan and a Masonic charity project to erect a double monument in honour of Descartes.

2 Stéphane Van Damme, Descartes. Essai d'histoire culturelle d'une grandeur philosophique (XVIIe-XXe siècle) (Paris, 2002).

3 Discours sur l'origine, les progrès, et les révolutions de la Franc-maçonnerie philosophique, contenant un Plan d'Association \& un Projet Maçonnique de bienfaisance, pour l'Erection d'un double Monument en l'honneur de Descartes, By Brother Beguillet, Parliament Lawyer and General Secretary of the L(odge) of La Réunion des Etrangers (Philadelphia, 1784), 37: 'Léloge maçonnique de Descartes sera suivi d'une 
The second document was aimed solely at the membership of one of the most prominent lodges in Paris, the Amis Réunis, which was made up of fermiers-généraux (tax collectors during the Ancien Régime), high-finance workers, foreign travellers of quality and theatre amateurs plus the artists under their protection. The lodge wrote in its visitors' book that the Brothers 'wanted to form a society of friends much like the English clubs'. The secretary also felt it necessary to specify in the register's margin 'or clubs, or coteries in French' and then on the next folio 'a coterie of respectable people." To my knowledge, this is a unique case in the documentation currently available. This attempt by the actors themselves to define their own form of sociability is interesting because it resonates with a definition given half a century earlier by René-Louis de Voyer, marquis d'Argenson and future Foreign Affairs Minister from 1744 to 1747, of the famous Club de l'Entresol in his Mémoires:

The ecclesiastic [Alary] formed a small establishment whose history, now already unknown to many, will soon be forgotten by all. It deserves to be recorded nevertheless. It was an English-type club, in other words a wholly liberal political society, made up of people who liked to debate current affairs. They would meet up and express their opinions without fear of being compromised, because they were all acquainted with one another and therefore knew who they were talking with and in front of. This society was called the Entresol, because the place where they met was an entresol. It was where the ecclesiastic Alary lived. It had all manner of creature comforts: comfortable seats, a good fire in winter and windows that opened onto a pretty garden in summer. There was no lunch or dinner provided, but there were cups of tea in winter and lemonade and chilled liqueurs in summer. There was also a permanent supply of French, Dutch and even English newspapers. In short, it was a café for respectable folk. ${ }^{5}$

All of this points to the fact that eighteenth-century sociability was not just a social and cultural affair but also an association plan and a reflection

exposition de sa philosophie trop peu connue, et qui est tombée presque totalement depuis que l'Anglomanie nous a engoués d'un système étranger'.

4 National Archives, 177 AP 1, Taillepied de Bondy papers, Amis Réunis visitors' book, commenced 16 February 1777, fols. 7-8.

5 René Louis de Voyer de Paulmy, Marquis d’Argenson, Journal et mémoires du Marquis d'Argenson, ed. E. J. B. Rathery (Paris, 1859-67), vol. I, 96-10o. 
on its modalities. It is worth noting that a lodge in Perpignan even deliberately chose to change its name to La Sociabilité. ${ }^{6}$

\section{Conflictual dynamics}

Anglo-French Masonic relations - Scotland is a case apart, which I will individuate - thus bore the mark of rivalry and conflict rather than of fraternal emulation, and there were significant interactions in diplomatic circles. This was particularly true in the Baltic and the Levant, where the two countries had been vying with one another since the seventeenth century. The account given by Charles Tullman, provincial English Grand Master for Sweden since 1765 and Secretary to the London Ambassador to the Stockholm Court, is very illuminating in this respect. He had decided 'to force the lodges that are working with French constitutions here [in Sweden] to follow his dictates." With the support of his superior, Ambassador Sir John Goodricke, who was also a Freemason, he deployed a considerable amount of zeal and proselytised. Similar situations were also to be found in Naples, Warsaw and St Petersburg.

The conflict was political, territorial and symbolic. In fact, from the middle of the eighteenth century until nowadays, the Grand Lodge of England has claimed the 'universal motherhood' of London, the merging of the four London lodges giving birth to the Grand London Lodge in 1717; the writing of Anderson's Constitutions in 1723 and in 1738 are not only considered as reference dates in the history of English Masonry but as the birth marks of 'modern' Masonry around the world.

Paris offered London a treaty of alliance (which was in reality a treaty of mutual non-interference) which stipulated that in order to maintain the union and amity between them, the Grand Orient de France and the Grand Lodge of England will maintain a mutual correspondence,, ${ }^{8}$ and in particular that 'the Grand Orient de France will have complete executive jurisdic-

${ }^{6}$ 'Our lodge is almost entirely made up of the cream of Roussillon nobility, who will be happy to set an example of propriety and virtue' (Bibliothèque Nationale de France, Manuscripts Department, Masonic collection, FM $^{2}$ 349, Sociabilité file, 22 March 1783).

7 'die hier illegal arbeitenden Logen französischen Systems zu zwingen, sich mir [Tullman] unterzuordnen'. Cited by Roger de Robelin, 'Die Freimaurerei in Schweden im 18 Jahrhundert', Gold und Himmelblau. Die Freimaurerei, Zeitloses Ideal (Abo, 1993), 66.

8 Bibliothèque Nationale de France, Manuscripts, Masonic collection, FM ${ }^{1}$ 118, fol. $408 \mathrm{v}$, article 3 . 
tion in its territory. ${ }^{9}$ Paris stated, moreover, that 'the intention of the Grand Orient de France is to negotiate this equality, which has to form the basis of the treaty of alliance, with the Grand Lodge of England on equal terms. ${ }^{10}$ London, of course, rejected their demand for parity and their conception of the Masonic space:

The equality of the $1^{\text {st }}$ article cannot happen not least because Germany, Sweden and Holland have unanimously recognised the Grand Lodge of England, which can prove that it established the first National Grand Master in France, as their Mother ... It does not understand how the $2^{\text {nd }}$ article wishes to constrict the Grand Lodge, which was established in London within range of the British Government, when its branches extend out into all parts of Europe. ${ }^{11}$

The balance of power and the principle of equality that Paris was trying to impose on London at the beginning of the negotiations had two aims. Internally, it wanted to force the lodges that had been set up in France by London to renounce their English allegiance, and to have them re-established by Paris. The Anglaise in Bordeaux was singled out in particular and ostracised from the national Masonic community during its construction. Externally, Paris was seeking alliances in Europe and was opening up negotiations with Masonic Obediences across the Continent in order to isolate London and promote its own model of independent national Obediences, whose jurisdictions would be merged with state boundaries. The existence of this conflictual dynamic (because it was indeed a dynamic), which brought two conceptions of the Universal Republic of Freemasons into confrontation, is therefore undeniable. One was a 'cosmopolitan' conception, espoused by London, which 'limited' its demands to the recognition of its moral authority over the Order. The other was a 'national' conception, championed by Paris.

9 Bibliothèque Nationale de France, Manuscripts, Masonic collection, FM ${ }^{1}$ 118, fol. $408 \mathrm{v}$, article 2.

10 Bibliothèque Nationale de France, Manuscripts, Masonic collection, FM ${ }^{1}$ 118, fol. 408r, article 1.

11 Freemasons' Hall, London, Archives of the United Grand Lodge of England. 


\section{Intense interactions}

This rivalry did not, however, prevent intense interactions and exchanges between the two, which were a notable social connection between the two nations. Although the negotiations between the French and English Grand Lodges were marked by many tensions, they mobilised cultural and scholarly mediators of the first order. This was most notably the case with the astronomer Jérôme Lalande, Professor at the Collège Royal, and the ecclesiastic Rozier, editor of the Journal de Physique. Both these men regularly stressed their links with the Royal Society and the English scientific communities, proof once more that Masonic sociability fitted into the social environment with which it had forged close ties. For example, in 1773 Lalande wrote to London:

The Grande Loge de France - or, rather, the Grand Orient that has now been put in place - has long wished to develop a relationship with the Grand Lodge of England. Mr des Vignoles has sometimes written to us on this subject. As I cannot see him in the directory of grand officers, printed in 1773 at 1 Cole Newgate Street, I thought it best to return to source and contact you.

Mr de Luc, a skilled physician and close friend of mine, ${ }^{12}$ who stayed with you last year, has assured me you will be kind enough to honour me with a response and this I earnestly request of you.

My position as Senior Warden of the Grande Loge de France obliges me to ask you some questions. If you do not have the time to respond, I would be grateful if you could send me the name and address of the Grand Lodge's Correspondence Secretary so that I might address myself directly to him. It is no problem for him to write to me in English. In the two years since Freemasonry in France took on a new shape and adopted new activities, we have set up and reformed more than 200 lodges ...

I would also like to ask you if the Grand Lodge of England has received the two most recent annual reports that we had printed for you, showing our Statutes, the charts of our lodges and a list of our officers.

12 Jean-André De Luc (1727-1817) was a Genevan geologist of Huguenot origins as well as Queen Charlotte's reader in London from 1773 onwards. The scientific correspondence that De Luc maintained with the queen was published in 1779 under the title Jean-André De Luc, Lettres physiques et morales sur l'histoire de la Terre et de l'Homme (La Haye, 1779 and Paris, 1779). I am preparing to publish De Luc's personal papers, preserved at the Sterling Memorial Library of Yale University, New Haven, CT, which contain friendly and scholarly correspondence with Lalande. 
I can send you them if you wish and would be grateful if you could send me your reports from London. You could have them taken to the home of the bookseller Elmsley or to Mr Nourse's residence, who both often have occasion to come to France. If you have someone who would like to establish a correspondence between the two Grand Lodges through me, that would be very pleasing for both sides.

I would be interested to know where the Grand Lodge assembles and whether the plan to contribute to the purchase of a house has gone ahead as planned in 1773. Does the Grand Lodge have a building or public establishment in London or Scotland?

Please excuse me for the liberty I have taken in importuning you on account of my zeal for Freemasonry, which must be as dear to you as it is to me judging by the eminent position you hold.

I am with respect

Sir

Your very humble and obedient servant

Delalande

From the Académie des Sciences and the Royal Society of London, at the Collège Royal, Place de Cambrai. ${ }^{13}$

Likewise, in preparation for the 1787 convent (general meeting), the Philalèthes (literally, lovers of truth), who were a mystical Masonic society that brought together the cream of Parisian society and their counterparts from across Europe, decided to question the Grand Lodge of England (which they considered to be the repository of the Order's history) on the origins of Freemasonry and the ancient archives that the English Brothers had preserved. The following extract is from the memorandum addressed to their counterparts in France and abroad:

It would seem useful to ask England how far back the Archives and Protocols of their first ones [Lodges] go to see if they have proof that Freemasonry existed in the previous century somewhere and also to gather together all the Blue Lodge degrees [Entered Apprentice, Fellowcraft and Master Mason] and more particularly the Catechisms that are not used in their studies. ${ }^{14}$

13 London, Freemasons' Hall, Grand Lodge Library, Archives of the United Grand Lodge of England, undated.

14 Charles Porset, Les Philalèthes et les Convents de Paris, Une politique de la folie (Paris, 1996). 
While London was seen as the repository or even the model of Freemasonry's origins, France was, in turn, where many English Freemasons generally discovered the Masonry of Adoption (open to women) and where they practised sociable Masonry. The case of Lady Colebrooke, who lived in Boulogne, illustrates this well. In his Journal, Abot de Bazinghen, a member of the local nobility, mentions the existence of a Lodge of Adoption in 1781 in Boulogne-sur-Mer, which initiated representatives from the local high society, including his own wife. The Grand Mistress was Milady Colebrooke, and her daughter, Miss Colebrooke the elder, was First Director (the female equivalent of the Senior Warden in the male lodges). The Journal states that just after Mrs de Bazinghen's initiation, 'Brother Comte de la Mark - Worshipful Master of the military lodge Parfaite Union - gave a superb banquet, after which, at two o'clock in the morning, the Colebrook ladies left Boulogne for Soissons where they had rented a house.'15 $\mathrm{Mr}$ and Mrs Bazinghen had become acquainted with the Colebrooke ladies a few months earlier when they had helped to distribute a play staged by a selectively recruited amateur theatre troupe. This is a particularly interesting example because, with only a few exceptions (which are scantly documented elsewhere), women were reputed to be absent from the lodges in England. Given their composition in the nineteenth and twentieth centuries, the English lodges can be considered a priori to be societies for men, whereas the French Freemasons seem to have followed the example of Brother Choderlos de Laclos (who had penned a plea to open the temples to women $)^{16}$ and welcomed Sisters into the temple of the Fraternity more readily. As such, they pioneered the trend for Women's Freemasonry and the Masonry of Adoption and are thought to have been the main contributors to its diffusion on the Continent. It would be worth carrying out a detailed study in this domain to take into account national representations or stereotypes and established memberships.

Leaving France's northern coast behind and travelling down to its capital, we find the famous Lodge of the Neuf Sœurs (a reference to the nine Muses), which was often presented as a symbol of the growing appeal of the Parisian centre in the final third of the eighteenth century. The prestige of this lodge was linked to the memory of fermier-général and philosopher Helvétius, who had nurtured a plan before he died to found a 'Sciences' lodge with the support of the astronomer Lalande. His project was taken

15 Alain Lottin (ed.), in collaboration with Louisette Caux-Germe and Michel de Sainte-Maréville, Boulonnais, Noble et Révolutionnaire. Le journal de Gabriel Abot de Bazinghen (1779-1798) (Arras, 1995), 68.

16 Besançon Public Library, manuscript Z 377 (4). 
up by the society or 'salon' that his wife had formed in Auteuil. The Neuf Sœurs also owed its reputation to the celebrity of its Worshipful Master, Benjamin Franklin, and to the fact that it had welcomed Voltaire in 1778, a few weeks before his death. ${ }^{17}$ Unlike the Neuf Sœurs in Paris, the lodges across the Channel were reputed to be more circumscribed in their public activities in the eighteenth century (this is still the case today). They would limit their interventions in the secular domain (i.e., outside of the Temple, in city life) to charity work for contemporary charitable organisations. However, in reality the picture here too was more nuanced. First of all, three lodges in European capitals (Paris, London and St Petersburg) had adopted the name of the ancient Muses in the 1770s. The Lodge of the Nine Muses in St Petersburg had set the ball rolling in 1774 with its constitutions from the Grand Lodge of England, which gave it the identification number 466. The Parisian lodge followed in 1776, and on 25 March 1777 the London lodge was formed, with the identification number 235. It met at the Thatched House Tavern in St James's Street. ${ }^{18}$ All three lodges were linked to their respective science academies. The global environment was undoubtedly favourable to the spread of a sociable Freemasonry, in line with the expectations of the urban elite, across Europe and in the British isles.

Within the context of London Masonry, the Lodge of the Nine Muses was not just another high society lodge. It was majorly connected to the Royal Society, for example, and it claimed to adhere to the Newtonian legacy espoused by Jean-Théophile Désaguliers. It also welcomed many Brothers and visitors from overseas, particularly Italians and Russians. Its founder, Bartolomeo (Bartholomew) Ruspini (1728-1813), a famous surgeon and philanthropist and protégé of the Prince of Wales, was himself of Italian origin. ${ }^{19}$ It was Ruspini's intention with the Lodge of the Nine Muses

17 Louis Amiable, Une loge maçonnique d'avant 1789, la loge des Neuf Soeurs (Paris, 1897), supplemented with a commentary and critical notes from Charles Porset (Paris, 1989).

18 Significantly, other societies and clubs would meet in this tavern, which was located in an area that represented the social centre of the London elites. [Lodge of the Nine Muses. no. 235], A centennial sketch of the history of the Lodge of the Nine Muses, 1777-1877. Presented to the Brethren at the centennial festival, held at Long's Hotes, Old Bond Street, London, on Tuesday, May the 8th, 1877, [London: Unwin Brothers, Printers]. Further information is available on the lodge's website: http://www. ninemuses.org.uk/html/library.html and particularly in the e-book published by the lodge in 2012: http://www.ninemuses.org.uk/historybook/.

19 He is the subject of a biographical note written by Isabelle Krihiff-Aguirre in $L e$ Monde maçonnique des Lumières (Europe/the Americas E Colonies). Dictionnaire 
to show the influence of the London lodge in Europe and to affiliate the foreign visitors who converged on the English capital. Most notable among them was Pascal Paoli, who was welcomed as a member. The lodge also corresponded with its Parisian sister, the Neuf Sœurs.

\section{English-origin Blue Lodge degrees and French-origin 'Scottish' degrees}

In order to understand the importance of Franco-British Masonic interactions, we need also to focus on the success of the French high degrees. These were often perceived as having devalued the three primary degrees of English Masonry (Entered Apprentice, Fellowcraft and Master), which were judged to be too simplistic and not selective enough. The French high degrees emphasised the chivalrous, Christian nature of Freemasonry and allowed orders to organise lavish ceremonies with highly elaborate decors and settings. Once again, though, this situation was not clear cut because it was possible to combine a commitment to the three 'English' primary degrees and the trend for the 'French' high degrees, whose paternity incidentally the French symbolically attributed to the Scottish. ${ }^{20}$ This tendency to attribute the Order's origins to medieval Scotland rather than to England descended from Jacobite Andrew Ramsay's 1737 Discours. There are numerous (and some unexpected) records of this, not least among which is the account of Jean-Paul Marat, who was doctor at the time to the Comte d'Artois's security entourage. He was welcomed as a Mason in London and admitted into the swanky Temple of the La Bien Aimée Lodge in Amsterdam on account of his French-origin high degrees. On 10 October 1774, with his certificate from the London lodge the Misericorde in hand, he signed the Amsterdam lodge's visitors' book.$^{21}$ Fifteen years earlier, in 1759 , Casanova had also visited the prestigious Dutch lodge and invented a high degree for himself in his entry in the visitors' book: 'Giacomo Casanova of

prosopographique, ed. Charles Porset and Marie-Cécile Révauger (Paris, 2013), III, $2422-4$.

20 This is still the case. Incidentally, the most frequently practised rite in the world is currently the Ancient and Accepted Scottish Rite of Freemasonry. Beyond its symbolic reference, however, its origins lie less in Scotland and more in a broad Atlantic movement that went from Bordeaux to Haït, on to Charleston and then back again to France.

21 The Hague, Orde van Vrijmetslaren onder Het Grootoosten der Nederlanden, Archief, carton 4337, 41: Visiteurenboek van de loge La Bien Aimée, minutes dated 10 October 1774 . 
the Saint André Lodge in Paris, Grand Inspector of all lodges in France.,22 Moreover, he recounted the episode in Histoire de ma vie:

M. D. O. - a merchant from Amsterdam - invited me to dine with him at the burgomasters' lodge. This was a true honour, because despite all the usual rules of Masonry, it would only admit its twenty-four members. These were the wealthiest millionaires in the Bourse [the Amsterdam Stock Exchange]. He told me he had announced me and that the lodge would be opened in French because of me. They were so happy to have me that they declared me supernumerary for the entire duration of my stay in Amsterdam. M. D. O. told me the next day that the company I had dined with had three hundred million between them. ${ }^{23}$

This was undoubtedly an exaggeration, but it is nevertheless an interesting source because of Casanova's combining of the three English-origin primary degrees, which would have allowed him to be recognised anywhere in the world as a Brother, and the French-origin high degrees, which enabled access to the smartest Masonic cenacles. He wrote, moreover: 'Two months later [after being initiated as a Freemason in Lyons], I became first a Fellowcraft and then a Master in the Duke [sic] of Clermont's lodge in Paris. ${ }^{24}$ There is no higher degree in Freemmasonry [sic]. Those who imagine themselves to be higher because of the new titles that have been invented are mistaken, or else they want to deceive. ${ }^{25}$

This Franco-British combination was not just a characteristic of individuals but was also expressly adopted by those lodges situated at the interface of oceanic and colonial spaces, such as the Heureuse Rencontre in Brest, or at the meeting point of different linguistic areas, such as the Candeur in Strasbourg. Both of these are good illustrations of the dynamics at work

22 The Hague, Orde van Vrijmetselaren onder Het Grootoosten der Nederlanden, Archief, carton 4337, 41: Visiteurenboek van de loge La Bien Aimée, 1759.

23 Casanova, Histoire de ma vie, published under the guidance of Gérard Lahouati and Marie-Françoise Luna, in collaboration with Furio Luccichenti and Helmut Watzlawick (Paris, 2013), II, 225.

Louis de Bourbon-Condé (1709-71), Comte de Clermont, Grand Master of the Grande Loge.

25 Casanova, Histoire de ma vie, I, 590. Casanova's first draft read as follows: 'Two months later, I received the second degree in Paris, and a few months after that the second degree [of Entered Apprentice], and a few months after that the third, which is the Mastery. This is the ultimate. All the other titles that have been given to me over time are pleasant inventions, which although symbolic add nothing to the dignity of the degree of Master' (Casanova, Histoire de ma vie, I, 1025-6). 
and the plasticity of the different forms of Masonic sociability that existed during the Enlightenment.

\section{English recognition of the Brest and Strasbourg lodges}

The 'Livre d'Architecture', which was the register of minutes taken at the assemblies and meetings of Loge Anglaise no. 184, reveals that the Heureuse Rencontre, which numbered many naval officers among its membership (it is important to highlight this point because of the Anglo-French naval rivalry), had a dual identity. Preserved at Finistère's Departmental Archives, the register covers a period from the creation - or 'installation' of the Brest Lodge on 18 May 1774 to the end of the Revolutionary period. ${ }^{26}$ The circumstances of this lodge were original, to say the least, because it was 'known to the Grand Orient de France under the title of Heureuse Rencontre and to the Grand Lodge of England as no. 184.'27

The lodge's decision to come under the jurisdiction of two Obediences at the same time, one of which was foreign, represented a considerable amount of additional administrative work. It meant that one community of Freemasons had to actuate two independent lodges, practise different rituals, keep two registers of all minutes, correspondences and accounts, elect two colleges of officers every year and so on. This task was complicated by the fact that London was in the habit of writing in English to its continental foundations while the use of French was common in eighteenth-century European Masonic correspondence (even when documents did not cross the border). The translation of English regulatory texts and of the documents sent by London was therefore a laborious prerequisite. It was also compulsory for all Freemasonry collective reflections and practices to be recorded in French. Trying to match the English and French Masonic uses, or at least to find some similarities between them, also necessitated the

Archives Départementales du Finistère, $40 \mathrm{~J}$ 47, Loge Anglaise $n^{\circ} 184$, Livre d'Architecture 1774-year VI.

${ }^{27}$ The Masonic collection in the Bibliothèque Nationale de France's manuscripts department holds an identical Livre d'Architecture from the Heureuse Rencontre under the classification $\mathrm{FM}^{3}$ 261: 'the present register containing two hundred and forty-eight pages including the present one has been classified and signed by us on the first and last pages and handed over to the archives of the Heureuse Rencontre Lodge to be used for registering the minutes and deliberations of the symbolic lodges' meetings for the degrees of Entered Apprentice Fellowcraft; and M[aster] Mason. Brest Lodge, Year of Light 5773 - symbolically, the Masonic calendar begins at the world's creation ... 4,0oo years ago.' 
long but interesting task of compiling and comparing all the documents, which was the responsibility of the Commissioners. There is evidence of this in the archives:

1. The lodge adopts in their entirety the Commissioner's comments on lodge no. 184's request for the distinctive title of Heureuse Rencontre should some English lodges have distinctive titles as well as their numbers.

2. On the request to the Very Respectable Grand Lodge of England for the functions attributed to each officer in English lodges and on the delivery to them of those attributed to date to the officers we recognise in our lodge.

3. On the request to the Very Respectable Grand Lodge of England for the degrees that it recognises, their relative ranks, those that are due honours, the type of honours, how they are conferred, how each degree operates (working or banquet lodge) and how each of them is pictured.

4. On the delivery to the Very Respectable Grand Lodge of England of the names of the degrees that we have given to date in the lodge as well as the names of those that we are familiar with.

5. On the request to the Very Respectable Grand Lodge of England for an overview of the lodges that it recognises as being properly constituted.

10. On the delivery to the Very Respectable Grand Lodge of England of the signs, words and touches that we believe to be the new English recognition with a request to be so kind as to tell us if it is genuine, and if it is not and if there is one, to please pass them onto us. ${ }^{28}$

Some members of the lodge had undoubtedly under-estimated the drawbacks of such a situation, including the Worshipful Master, who was presiding over the work himself, as his declaration to the lodge's Commissioners on 26 June 1776 shows:

[the Worshipful Dudezerseul declares] that the reason for these comments and protestations over the meeting of 25 June was the belief that

28 Bibliothèque Nationale de France, Manuscripts, Masonic collection, $\mathrm{FM}^{3}$ 261, 'Livre d'Architecture of the Heureuse Rencontre', Brest Lodge, minutes from 16 May 1774, fols. $44-5$. 
since the French and English lodges form one single lodge under the name of Heureuse Rencontre no. 184, these two lodges must by rights have the same officers. However, having read articles 3 and 17 of the Grand Lodge of England's general regulations and their comments on the articles to the Grande Loge on 16 May, we accept that the French and English lodges are absolutely distinct and separate and that they are independent of one another. ${ }^{29}$

Given the risks of confusing the two structures, a meeting was convened to arrive at some clarification. The Commissioners explained to the Brothers that 'since the lodge [no. 184] has considered that it has specific rules that are distinct from those of the Grand Orient de France and, further, that the head of Lodge no. 184 only has authority at the behest of the Grand Lodge of England, this lodge cannot be merged with the Heureuse Rencontre Lodge. ${ }^{30}$

If the Freemasons in Brest accepted the complexity of such an organisation and, consequently, the uncertainties and awkwardness of the separation, it was clearly because it was in their interests to do so. For them, the English affiliation in $\mathbf{1 7 7 2}$ in no way meant a renunciation of almost thirty years of the French Masonic practices which they had been adhering to since 1745, and likewise the lodge's formation through the Grand Orient de France did not imply more of a separation with London. Herein lies the ambiguity, but also the richness, of the Brest Lodge's situation. The matter of the high degrees is a good example of this. One of the keys to the success of French Freemasonry in Europe was without a doubt the existence of these high degrees, which were mainly Christian and chivalrous in essence. So, when they linked up with English Freemasonry, it may have seemed at first glance that they would have had to abandon the high-degree rituals. In reality, the situation was more complex, and the choice of constituent power proved decisive. English Freemasonry was not monolithic. While the Grand Lodge of the Moderns believed, up until the 1813 Act of Union, that 'pure Ancient Masonry comprised three degrees and no more', its rival the Grand Lodge of the Ancients practised the Royal Arch high degree. It was the Ancients who had granted the constitutions to the Brest Lodge, a choice that demonstrates that they had a good knowledge of the Masonic situation in England (arguably through geographic proximity). This

29 Archives Départementales du Finistère, 40 J 47, English Lodge no. 184, Livre d'Architecture, fol. 19, 26 June 1776.

30 Archives Départementales du Finistère, 40 J 47, English Lodge no. 184, Livre d'Architecture, fol. 20, 8 September 1776. 
contrasts sharply with the relative lack of knowledge that Lalande showed in his aforementioned 1773 letter, despite the fact that he was Grand Officer of the Grand Orient and a member of the Royal Society.

The Brest Lodge is proof that Freemasons during the Enlightenment knew how to make the most of the opportunities afforded them by a plural Fraternity. They practised supplementary high degrees, whose foreign origins just made them all the more appealing. Once reattached to the Grand Orient, the Heureuse Rencontre's autonomous existence in relation to Lodge no. 184 allowed it, after much skilful manoeuvring during meetings, to simultaneously pursue the practice of the French high degrees. For example, on 7 September 1782 'the Worshipful Master ... read out the regulation to be observed in the English lodge no. 184, at the Brest Lodge ... and convened an English lodge for the lodge's "chevaliers de l'orient" [one of the principal French high degrees] in order to confer on them the Royal Arch degree on the first Saturday of next month. ${ }^{31}$

Not only did the Brest Brothers succeed in combining the English and French degrees, they also integrated both of them into a newly created scale of degrees. They clearly found this system to their satisfaction because, when their lodge came out of hibernation in September 1797 after five years of interruption to its work as a result of the Revolution, ${ }^{32}$ they were happy to abide with the obligation from the new political regime to change the name Royal Arch to Parfait Arch. ${ }^{33}$

The Breton lodge's decision to have a dual French and English identity also offered the potential to nurture stimulating and enriching relations with lodges in other countries while, at the same time, not isolating itself in regard to its regional Masonic fabric - in contrast to the situation which its mother lodge, the Anglaise in Bordeaux, once found itself in. The Brest Lodge was mainly composed of naval men, but it also regularly welcomed foreign visitors. It offered assistance to shipwrecked sailors, such as Robert Wyneau (a member of the Perfect Amity no. 230 in Bath) and Captain Wreitt from Limerick, and to merchants, all of whom opened up new horizons for the Brest community. ${ }^{34}$ Moreover, the lodge was subject to an increasing number of requests from Brothers who wanted to gain access

Archives Départementales du Finistère, 40 J 47, English Lodge no. 184, 'Livre d'Architecture', fol. 43r, 7 September 1782.

32 Their work was interrupted in October 1792.

33 Archives Départementales du Finistère, 40 J 47, English Lodge no. 184, 'Livre d'Architecture', fol. 72v. The lodge's minutes made reference at the time to 'la République française une et indivisible' (the French Republic, one and indivisible).

34 Archives Départementales du Finistère, $40 \mathrm{~J}$ 47, English Lodge no. 184, 'Livre d'Architecture', fol. 41r, fol. 58v. 
to England or another country through an English Masonic certificate. Some of the problematics developed by Renaud Morieux in his thesis on the Channel as the Anglo-French border were therefore visible here in the masonic domain. ${ }^{35}$

The Brest Lodge had proved in its own way that, with adaptability and diplomacy, it was possible to retain a considerable amount of room for manoeuvre in relation to the Obediences and their drive for centralisation. It is worth noting that this approach appeared to comply with the regulations enacted by the Grand Orient: 'all lodges situated within the territory of one Grand Orient will be able to request and obtain aggregation letters from another Grand Orient, but they will only be delivered to those lodges equipped with local constitutions and the consent of the Grand Orient that those lodges depend on. ${ }^{36}$ Moreover, the Heureuse Rencontre never sought to hide the fact that its Brethren also belonged to the Grand Lodge of England. It was a unique case, and the Chambre des Provinces in Paris, which was extremely pernickety in ensuring that respect for Masonic orthodoxy was maintained within the Grand Orient, could not dispute the legality of their decision. ${ }^{37}$

The national logic that was increasingly asserting itself across Masonic Europe at the end of the eighteenth century did not therefore exclude a commitment to the principle of a broad, cosmopolitan space. Neither wholly English Freemasons nor wholly 'French Freemasons' (in the contemporary sense of the expression), the Brest Freemason community had constructed its own identity.

In Strasbourg, the Brothers of the Candeur, a lodge that was closely linked to the university and aimed at persons of note, worked under the leadership of Pierre de Guenet. Originally from Languedoc, he had been present at the origins of Freemasonry in France and never missed an opportunity to remind his Parisian interlocutors of the fact: 'About forty years ago, ${ }^{38}$ I was received by Milord Darwentwater, who was Grand Master at the time $\mathrm{e}^{39}$ and who received all the court nobles, and I have been witness

35 Renaud Morieux, Une mer pour deux royaumes. La Manche, frontière franco-anglaise XVIIe-XVIIIe siècles (Rennes, 2008).

36 Bibliothèque Nationale de France, Manuscripts, Masonic collection, FM $^{1}$ 118, commission for foreign Grand Orients, fol. 408r, 7 March 1775.

37 A letter from the Heureuse Rencontre was in fact read out at the Chambre des Provinces on 4 June 1774. It explicitly mentioned the constitutions granted by the Grand Lodge of the Ancients.

38 His letter written from Strasbourg is dated 22 April 1773.

39 Charles Radcliffe, Lord Darwentwater (1693-1746) was Grand Maître from 27 December 1736 until 1738. It is likely he left the post after the pope had fulminated 
to all the progressions and variations that the order has undergone. My zeal and steadfastness have led me to the reform [the Templar reform that spread from Dresden in Saxony] that was introduced to me a long time ago. ${ }^{\prime 40}$ By 1765 , when the Grande Loge de Paris (the Obedience succeeded by the Grand Orient in 1771-77) was in crisis, he could not find words harsh enough to criticise the laxity of French Freemasonry:

All of Germany, Russia and Italy wholeheartedly reject, through a comprehensive reform, these so-called Brothers, who through either their state of origin or their customs should not be members of this Great Republic. There is no more anarchy than in France. Masonry in this country is just an object of amusement, for the most part seen as an opportunity to swindle or gorge on food and drink. We must only be interested in frivolity, and we will be the last to restore masonry to its first institution. Only by following it can we achieve its aim. ${ }^{41}$

Although the new Obedience intended to impose its law on the provincial lodges, it sought to break with Paris and requested patents from London instead:

Driven to desperation by the fanciful, self-seeking claims of the so-called Grande Loge, which has resumed its position (under the name of Grand Orient), we deemed it Necessary for the Good of the Order to turn to England where Masonry has been preserved in all its simplicity and purity, and we have obtained constitutions from them. ${ }^{42}$

At the same time, De Guenet made contact with the emissaries of the Templar reform from Saxony, who were bringing with them a plan for the radical reform of the Masonic Order that was chivalrous and Christian in essence. While this was far removed from the English Masonic model, it was known to be thriving in Saxony:

the bull in eminenti in May 1738. The last mention of his Masonic activity is in

December 1739 at a meeting at which he was present in his capacity as former Grand Master. He was executed after the Jacobites' defeat at the Battle of Culloden.

41 Bibliothèque Nationale de France, Manuscripts Department, Masonic collection, FM $^{1}$ 111, Chapelle collection, tome VI, fol. 445r, 22 January 1765.

42 Bibliothèque Nationale Universitaire de Strasbourg, mss 5437, Registre des procèsverbaux de la loge de La Candeur constituée mère des loges du Grand Orient de Strasbourg [sic], 30 June 1772, fol. 271. 
Turning Away from the sorry spectacle now on offer to Us as a result of the schism that divides French Masonry and anticipating Only very slow and highly uncertain outcomes from the zealous efforts of the lodges in the Midi to resolve the situation, we have fixed Our attention and pinned our hopes on the operations of Northern Germany. ${ }^{43}$

While Brest chose dual recognition from France and England, Strasbourg chose both the path of Masonic reform with its conversion to Templar Masonry and a return to the Order's English origins as a source of stability. It is clear that French Freemasons were certainly never left indifferent by English Freemasonry in the eighteenth century. Moreover, this is still the case today because Freemasonry worldwide is still split between a self-proclaimed regular Freemasonry, that is, recognised as such by London, and a Liberal or Adogmatic Freemasonry, which is not recognised because it does not respect the landmarks defined by London. Even when they maintain that they have broken with the hegemonic claims of the Grand Lodge of England, the French Freemasons still define themselves in relation to the English. Hence, close attention paid to the different levels of relations in the Order and its management strata at local level would reveal a broad spectrum of attitudes and representations.

43 Bibliothèque Nationale Universitaire de Strasbourg, mss 5437, Registre des procèsverbaux de la loge de La Candeur constituée mère des loges du Grand Orient de Strasbourg [sic], 30 June 1772, fol. 272. 


\section{Bibliography}

\section{Primary sources}

Addison, Joseph and Richard Steele, The Spectator, ed. Donald F. Bond, 5 vols. (Oxford, 1965).

A New Academy of Complements; or, The Lover's Secretary (London, 1715).

A New Academy of Compliments (London, 1748).

Anon., Le Roman de Eles and L'Ordene de Chevalerie, trans. and ed. Keith Busby (Amsterdam, 1983).

An Useful and Entertaining Collection of Letters upon Various Subjects. Several Now First Published from Their Original Manuscripts, by the Most Eminent Hands (London, 1745).

[Baillie, John], The Patriot: Being a Dramatick History of the Life and Death of William the First Prince of Orange ... (London, 1736).

Beguillet, Edme, Discours sur l'origine, les progrès, et les révolutions de la Francmaçonnerie philosophique, contenant un Plan d'Association \& un Projet Maçonnique de bienfaisance, pour l'Erection d'un double Monument en l'honneur de Descartes Par le F[rère] Béguillet, Avocat au Parlement, Secrétaire Général de la L[oge] de la Réunion des Etrangers (Philadelphie, 1784).

Bellamy, John, Whig Club Instituted in May 1784 (London, 1792).

Bolingbroke, Henry St John, Lord, A Dissertation upon Parties, 1734, The Works of Lord Bolingbroke in four Volumes (London, 1967), II, 5-172.

— The Idea of a Patriot King, 1749, The Works of Lord Bolingbroke in four Volumes, II, 372-429.

Boswell, James, Boswell: The Applause of the Jury, 1782-1785, ed. Irma S. Lustig and Frederick A. Pottle (London, 1981).

_, Boswell in Extremes, 1776-1778, ed. Charles McC. Weis and Frederick A. Pottle (London, 1971).

— Boswell Laird of Auchinleck, 1778-1782, ed. Joseph W. Reed and Frederick Pottle (Edinburgh, 1993).

—, Boswell's Column, 1777-1783, ed. Margery Bailey (London, 1951).

—, Boswell's Life of Johnson, in two volumes, 1791, third edition 1799 (London, 1904).

—, The Life of Dr Johnson (1791; London, 1962). 
—, The Life of Samuel Johnson, LL.D., ed. R. W. Chapman (Oxford, 1980 edition).

—, Ode on Mr. Boswell's Gong, in The Edinburgh Magazine or Literary Miscellany

(Edinburgh, July 1785), Volume II, 181.

Brenan, Beaumont, The Painter's Breakfast (Dublin, 1756).

Brown, George, ed., The New and Complete English Letter-Writer; or, Whole Art of General Correspondence (London, [1770?]).

Brown, Thomas, Essays Serious and Comical (London, 1707).

Buckeridge, Bainbrigg, 'Dedication', in Roger De Piles, The Art of Painting, trans. John Savage (London, 1706).

Burke, Edmund, An Appeal from the New to the Old Whigs, 1791, ed. Norbert Col (Rennes, 1996).

—, A Philosophical Enquiry into the Origins of our Ideas of the Sublime and Beautiful, 1757, 1759, A Philosophical Enquiry into the Sublime and Beautiful and Other Pre-Revolutionary Writings, ed. David Womersley (London, 1998), 49-199.

- Letter to Richard Burke, 1792, The Works of the Right Honourable Edmund Burke, 6 vols. (London, 1907-10), VI, 61-80.

—, Letters on a Regicide Peace, 1796-97, The Works of the Right Honourable Edmund Burke, V, 152-354 and 358-433.

- Reflections on the Revolution in France, 1790, ed. Conor Cruise O'Brien, 1969 (Harmondsworth, 1982).

—, Reflections on the Revolution in France, ed. John C. D. Clark (Stanford, CA, 2001).

-, Reflections on the Revolution in France, ed. John G. A. Pocock, 1987 (Indianapolis and Cambridge, 2005).

- Speech on a Bill for the Relief of Protestant Dissenters, 1773, The Works of the Right Honourable Edmund Burke, VI, 102-13.

- Thoughts on the Cause of the Present Discontents, 1770, The Works of the Right Honourable Edmund Burke, I, 306-81.

- Vindication of Natural Society, 1756, 1757, A Philosophical Enquiry into the Sublime and Beautiful and Other Pre-Revolutionary Writings, ed. David Womersley (London, 1998), 1-48.

Campbell, Duncan, A Poem upon Tea. Wherein its Antiquity, its several Virtues and influences are set forth; and the Wisdom of the sober Sex commended in chusing so mild a Liquor for their Entertainments (London, [1734]).

Carmontelle, Louis de, Coup de patte sur le salon de 1779 (Paris, 1779). , Le Triumvirat des arts (Paris, 1783).

Casanova, Giacomo, Histoire de ma vie, ed. Gérard Lahouati and Marie-Françoise Luna, with Furio Luccichenti and Helmut Watzlawick (Paris, 2013).

Cibber, Colley, The Lady's Last Stake, or, The Wife's Resentment. A Comedy. As it is acted at the Queen's Theatre in the Hay-Market, by Her Majesty's servants (London, 1707).

Comte, Louis Le, Memoirs and Observations Topographical, Physical, Mathematical, Mechanical, Natural, Civil, and Ecclesiastical. Made in a late Journey through the Empire of China (London, 1697). 
Day, Angel, The English Secretorie Wherin is Contayned, a Perfect Method, for the Inditing of all Manner of Epistles and Familiar Letters, together with Their Diversities (London, 1586).

Defoe, Daniel, Defoe's Review, Major Single Works, ed. Arthur W. Secord, 22 vols. (New York, 1938).

—, A Tour through the Whole Island of Great Britain [1724-25] (London, 1971).

—, Roxana, The Fortunate Mistress (Oxford, 1981).

- The Complete English Tradesman (London, 1726).

De Luc, JeanAndré, Lettres physiques et morales sur l'histoire de la Terre et de l'Homme (La Haye, 1779 and Paris, 1779).

De Piles, Roger, Conversations sur la connaissance de la peinture et sur le jugement qu'on doit faire des tableaux, 1677 (Geneva, 1970).

Diderot, Denis, Salons 1759-1781, 4 vols. (Paris, 1984-95).

Feltham, John, The Picture of London, for 1806; Being a Correct Guide to all the Curiosities, Amusements, Exhibitions, Public Establishments, and remarkable Objects in and near London; with a Collection of Appropriate Tables (London, 1805).

Ferguson, Adam, An Essay on the History of Civil Society, 1767, ed. Fania Oz-Salzberger (Cambridge, 1995).

Fordyce, David, The New and Complete British Letter-Writer; or, Young secretary's instructor in polite modern letter-writing (London, [1790?]).

Garrick, David, The Songs, Choruses, and Serious Dialogue of the Masque called The Institution of the Garter (London, 1771).

Gignoux, John, ed., Epistolary Correspondence Made Pleasant and Familiar: Calculated Chiefly for the Improvement of Youth (London, 1759).

Goldsmith, Oliver, Retaliation; a poem (London, 1774).

Gwynn, John, An Essay on Design: Including Proposals for Erecting a Public Academy (London, 1749).

Hardy, Thomas, Memoir of Thomas Hardy, Founder of, and Secretary to, the London Corresponding Society (London, 1832).

Highmore, Joseph, Essays (London, 1766).

Hill, Aaron, Alzira. A Tragedy (London, 1736).

Hill, John, ed., The Young Secretary's Guide; or, A Speedy Help to Learning (London, 1719).

Hoffmann, Friedrich, Medicus Politicus (Lugduni Batavorum, 1738).

Hume, David, Essays Moral, Political, Literary, 1777, ed. Eugene F. Miller (Indianapolis, 1985).

Johnson, Samuel, 'Connoisseur', A Dictionary of the English Language (London, 1756).

, 'Review of A Journal of Eight Days' Journey by Jonas Hanway', The Literary Magazine; or, Universal Review 2, no. 13 (April 1757), 161-7.

—, The History of Rasselas, Prince of Abissinia, ed. J. P. Hardy (Oxford, 1999).

- The Letters of Samuel Johnson, ed. Bruce Redford, 5 vols. (Oxford, 1992), vol. I: 1731-1772; vol. II: 1773-1776.

Jones, John, The Bathes of Bathes Ayde (London, 1572). 
Kant, Immanuel, Anthropology, History, and Education, ed. G. Zöller and Robert B. Louden. (Cambridge, 2007).

— Idea for a Universal History from a Cosmopolitan Point of View (1784), ed. Lewis White Beck (Indianapolis, 1963).

Killigrew, Thomas, Chit-Chat: A Comedy (London, 1719).

[Kimber, Edward], The Ladies Complete Letter-Writer; Teaching the Art of Inditing Letters on Every Subject That Can Call for Their Attention, as Daughters, Wives, Mothers, Relations, Friends, or Acquaintance ...(London, 1763).

L'Estrange, Roger, Tears of the Press (London, 1681).

Lee, Arthur, A Second Appeal to the Justice and Interests of the People, on the Measures Respecting America. By the Author of the First (London, 1775).

[Lennox, Charlotte], The Female Quixote; or, The Adventures of Arabella (London, 1752).

London Corresponding Society, A General Meeting of the London Corresponding Society, Held at the Globe Tavern Strand on Monday the 2oth January 1794 (London, 1794).

Lottin, Alain, Louisette Caux-Germe and Michel de Sainte-Maréville, eds., Boulonnais, Noble et Révolutionnaire. Le journal de Gabriel Abot de Bazinghen (1779-1798) (Arras, 1995).

Loveday, Robert, Hymen's Praeludia: Or Love's Master-Piece: Being that So-MuchAdmir'd Romance, intitled Cleopatra (London, 1736).

Lucas, Charles, Essay on Waters (London, 1756).

Macky, John, Journey Through England (London, 1714).

Malton, Thomas, A Compleat Treatise on Perspective, in Theory and Practice (London, 1775).

Mandeville, Bernard de, The Fable of the Bees, 1714, ed. Phillip Harth (London, 1970, 1989).

Montaiglon, Anatole de, Procès-verbaux de l'Académie royale de peinture et de sculpture, 10 vols. (Paris, 1875-92).

Motteux, Peter Anthony, A Poem in Praise of Tea (London, 1712).

Ogilby, John, Britannia (London, 1675).

Oliver, William, A Practical Essay on Fevers ... to which is Annex'd A Dissertation on the Bath Waters (London, 1704).

Ovington, John, An Essay upon the Nature and Qualities of Tea (London, 1699).

Paine, Thomas, Rights of Man, 1791 and 1792, ed. Eric Foner, 1984, notes Henry

Collins, 1969 (Harmondsworth, 1985).

Pasquin, Anthony, A Critical Guide to the Exhibition of the Royal Academy, for 1796 (London, 1796).

- A Critical Guide to the Present Exhibition at the Royal Academy, for 1797 (London, 1797).

—, A Liberal Critique on the Present Exhibition of the Royal Academy: Being an Attempt to Correct the National Taste; to Ascertain the State of the Polite Arts at this Period; and to Rescue Merit from Oppression (London, 1794).

—, Memoirs of the Royal Academicians, Being an Attempt to Improve the National Taste (London, 1796).

—, The Royal Academicians: a Farce (London, 1786). 
Paterson, William, Arminius. A Tragedy (London, 1740).

Pechlin, Johann, Theophilus Bibaculus, sive de Potu Theae Dialogus (Frankfurt, 1684).

Pepys, Samuel, The Diary of Samuel Pepys, ed. R. Latham and W. Matthews, 11 vols. (London, 1970-83).

Pernety, Antoine-Joseph, Dictionnaire portatif de peinture, sculpture et gravure, 1757 (Geneva, 1972).

Pindar, Peter, Farewell Odes for the Year 1786 (London, 1786).

—, Lyric Odes for the Year 1783 (London, 1783).

—, Lyric Odes for the Year 1785 (London, 1785).

Place, Francis, The Autobiography of Francis Place, 1771-1854, ed. Mary Thale (Cambridge, 1972).

Price, Richard, A Discourse on the Love of Our Country, 1789 (Oxford and New York, 1992).

Reynolds, Joshua, Discourses on Art, 1769-179o, ed. Robert R. Wark (New Haven, CT, 1997).

Richardson, Jonathan, A Discourse on the Dignity, Certainty, Pleasure and Advantage, of the Science of a Connoisseur (London, 1719).

Richardson, Samuel, Letters Written to and for Particular Friends, on the Most Important Occasions. Directing Not Only the Requisite Style and Forms To Be Observed in Writing Familiar Letters; But How to Think and Act Justly and Prudently, in the Common Concerns of Human Life. Containing One Hundred and Seventy-Three Letters, third edition (London, 1746).

Royal Academy of Arts, Abstract of the Instrument of Institution and Laws of the Royal Academy of Arts in London, Established December 10, 1768 (London, 1797).

Rutty, John, A Methodical Synopsis of Mineral Waters (London, 1757).

-, The Analyzer Analysed (London, 1758).

Shaftesbury, Lord (Anthony Ashley Cooper), 'Sensus Communis, an Essay on the Freedom of Wit and Humour in a Letter to a Friend', in Characteristicks of Men, Manners, Opinions, Times, ed. Lawrence E. Klein (Cambridge, 1999).

Smith, Adam, The Theory of Moral Sentiments (London, Edinburgh, 1759).

Smollett, Tobias, An Essay on the External Use of Water (London, 1752).

-, A Complete History of England (London, 1758-59).

—, Travels through France and Italy, 1766, ed. Jan Morris (London, 2006).

-, The Expedition of Humphry Clinker, 1771, ed. Lewis M. Knapp and PaulGabriel Boucé (Oxford, 2009).

, The Present State of all Nations (London, 1768-69).

Stanhope, Philip Dormer, Earl of Chesterfield, Letters Written by the Late Philip Dormer Stanhope, Earl of Chesterfield, to His Son, 2 vols. (London, 1774).

-, Principles of Politeness, and of Knowing the World; Being a New System of Education, by the Late Lord Chesterfield Containing Every Instruction Necessary to Complete the Gentleman and Man of Fashion, for the Improvement of Youth. (London, 1775).

Steele, Richard, The Tatler (1709-1711), ed. D. F. Bond, 3 vols. (Oxford, 1987).

Sterne, Laurence, A Sentimental Journey and Other Writings, 1768 (Oxford, 2003). 
Strange, Robert, An Inquiry into the Rise and Establishment of the Royal Academy of Arts (London, 1775).

Strype, John, The Survey of London, 2 vols. (London, 1720).

Swift, Jonathan, Journal to Stella, 2 vols. (Oxford, 1948).

- The Correspondence of Jonathan Swift, ed. Harold Williams (Oxford, 1963).

Tate, Nahum, Panacea: A Poem upon Tea: in Two Canto's (London, 170o).

Tavernier, John, ed., The Entertaining Correspondent; or, Newest and Most Compleat Polite Familiar Letter-Writer (Berwick, 1759).

Tea-Table: or, A Conversation between some Polite Persons of both Sexes, at a Lady's Visiting Day, The (London, 1725).

Tea, a Poem. In Three Cantos (London, 1743).

Tea. A Poem. Or, Ladies into China-cups; a Metamorphosis (London, 1729).

Thale, Mary, ed., Selections from the Papers of the London Corresponding Society, 1792-1799 (Cambridge and New York, 1983).

Thelwall, John, Selected Poetry and Poetics, ed. Judith Thompson (Basingstoke, 2015).

- The Politics of English Jacobinism: Writings of John Thelwall, ed. Gregory Claeys (University Park, PA, 1995).

- ed., The Tribune, a Periodical Publication, Consisting Chiefly of the Political Lectures of J. Thelwall, 3 vols. (London, 1795), vol. 1.

Thicknesse, Philip, Observations on the Customs and Manners of the French Nation, in a Series of Letters, in which that Nation is vindicated from the Misrepresentations of some Late Writers (London, 1766).

Thomson, James, Edward and Eleonora. A Tragedy (London, 1739).

Tocqueville, Alexis de, L'Ancien Régime et la Révolution, 1856, ed. J.-P. Mayer, 1964 (Paris, 1986).

Voltaire, Alzire, ou les Américains (Amsterdam, 1736).

Voyer de Paulmy, René Louis de, Journal et mémoires du Marquis d’Argenson, ed. E. J. B. Rathery (Paris, 1859-67).

Wallace, James and Charles Townshend, Every Man His Own Letter-Writer: Or, The New and Complete Art of Letter-Writing Made Plain and Familiar to Every Capacity... (London, 1782).

West, Gilbert, The Institution of the Order of the Garter (London, 1742).

\section{Secondary sources}

Acosta, Ana M., 'Spaces of Dissent and the Public Sphere in Hackney, Stoke Newington, and Newington Green', Eighteenth-Century Life 27 (2003), 1-27.

Allen, David F., 'Political Clubs in Restoration London', Historical Journal 19, no. 3 (1976), 561-8o.

Alpaugh, Micah, 'The British Origins of the French Jacobins: Radical Sociability and the Development of Political Club Networks, 1787-1793', European History Quarterly 44 (2014), 593-619.

Amiable, Louis, Une loge maçonnique d'avant 1789, la loge des Neuf Soeurs, second edition (Paris, 1989). 
Anderson, Benedict, Imagined Communities. Reflections on the Origin and Spread of Nationalism (1983; London, 2006).

Aronson, Nicole, Mademoiselle de Scudéry (Boston, 1978).

Aske, Katie and Kimberley Page-Jones, eds., La Sociabilité en France et en GrandeBretagne au Siècle des Lumières. Tome 6: 'L'insociable sociabilité: résistances et résilience' (Paris, 2017).

Ayres, Philip J., Classical Culture and the Idea of Rome in Eighteenth-Century England (Cambridge, 2009).

Badufle, Marjolaine, 'La sociabilité dans les Pensées de Montesquieu: Regard sur les femmes', in La Sociabilité en France et en Grande-Bretagne au Siècle des Lumières: Lémergence d'un nouveau modèle de société. Tome 4. Utopie, individu et société : la sociabilité en question, ed. Norbert Col and Allan Ingram (Paris, 2015), 73-92.

Ballaster, Ros, 'Satire and Embodiment: Allegorical Romance on Stage and Page in Mid-Eighteenth-Century Britain', Eighteenth-Century Fiction 27, no. 3/4 (2015), 631-6o.

Bannett, Eve Tavor, Empire of Letters: Letter Manuals and Transatlantic Correspondence, 1680-1820 (Cambridge, 2006).

— , 'Printed Epistolary Manuals and the Transatlantic Rescripting of Manuscript Culture,' Studies in Eighteenth Century Culture 36 (2007), 13-32.

Barclay, Craig, 'Heroes of Peace: The Royal Humane Society and the Award of Medals in Britain, 1774-1914' (unpublished Ph.D. thesis, Department of History, University of York, September 2009).

Barrell, John, "An Entire Change of Performances?" The Politicisation of Theatre and the Theatricalisation of Politics in the Mid 1790s', Lumen: Selected Proceedings from the Canadian Society for Eighteenth-Century Studies 17 (1998), 11-50.

- Imagining The King's Death: Figurative Treason, Fantasies of Regicide, 17931796 (Oxford and New York, 200o).

_- 'London and the London Corresponding Society', in Romantic Metropolis: The Urban Scene of British Culture, 1780-1840, ed. James Chandler and Kevin Gilmartin (Cambridge and New York, 2005), 85-112.

- The Spirit of Despotism: Invasions of Privacy in the 179os (Oxford and New York, 2006).

Barthes, Roland, The Fashion System (Oakland, 1983).

Bastin, Giselle, 'Pandora's Voice-Box: How Woman became the "Gossip Girl", in Women and Language: Essays on Gendered Communication Across Media, ed. Melissa Ames and Sarah Himsel Burcon (Jefferson, 2011), 17-29.

Batchelor, Jennie and Cora Kaplan, eds., British Women's Writing in the Long Eighteenth century: Authorship, Politics, and History (Basingstoke, 2005).

Beaurepaire, Pierre-Yves, ed., La Communication en Europe de l'âge classique aux Lumières (Paris, 2014).

Beljame, Alexandre, Le Public et les Hommes de Lettres en Angleterre au Dixhuitième Siècle, 1660-174.4 (Paris, 1881).

Benchimol, Alex, Intellectual Politics and Cultural Conflict in the Romantic period: Scottish Whigs, English Radicals and the Making of the British Public Sphere (Aldershot, England and Burlington, VT, 2010). 
Bercé, Yves-Marie, Révoltes et révolutions dans l'Europe moderne, 1980 (Paris, 2013).

Bergmann, Jörg R., Discreet Indiscretions: The Social Organisation of Gossip, trans. John Bednarz, Jr. (New York, 1993).

Binns, John, Recollections of the Life of John Binns: Twenty-Nine Years in Europe and Fifty-Three in the United States: With Anecdotes, Political, Historical, and Miscellaneous (Philadelphia, 1854).

Blanning, Tim, The Culture of Power and the Power of Culture: Old Regime Europe 1660-1789 (Oxford, 2000).

Borsay, Peter, The English Urban Renaissance: Culture and Society in the Provincial Town 1660-1770 (Oxford, 1989).

Boucé, Paul-Gabriel, 'Scotland and France in Smollett's Present States of All Nations, 1768-69', in Scotland and France in the Enlightenment, ed. Deirdre Dawson and Pierre Morère (Lewisburg, 2004).

Bourdieu, Pierre, La Distinction. Critique sociale du jugement (Paris, 1979).

— Le Sens pratique (Paris, 1980).

Boureau, Alain, 'The Letter-Writing Norm, a Medieval Invention', in Correspondence: Models of Letter-Writing from the Middle Ages to the Nineteenth Century, ed. Roger Chartier, Alain Boureau and Cécile Dauphin (Princeton, 1997), 24-59.

Bourke, Richard, Empire and Revolution: The Political Life of Edmund Burke (Princeton, 2015).

Bowers, Terence, 'Reconstituting the National Body in Smollett's Travels through France and Italy', Eighteenth-Century Life 21 (1997), 1-25.

Braddick, Michael, State Formation in Early Modern England, c. 1550-170o (Cambridge, 2000).

Brant, Clare, Eighteenth-Century Letters and British Culture (Basingstoke, 2006).

Brant, Clare and George Rousseau, eds., Fame and Fortune: Sir John Hill and London Life in the 1750s (Basingstoke, 2018).

Brewer, John, The Pleasures of the Imagination: English Culture in the Eighteenth Century (London, 1997).

— - Party Ideology and Popular Politics at the Accession of George III (Cambridge, 1976).

Brewer, John, Neil McKendrick and J. H. Plumb, eds., The Birth of a Consumer Society: The Commercialization of Eighteenth Century England (London, 1982).

Brims, John D., "The Scottish Democratic Movement in the Age of the French

Revolution' (Ph.D. thesis, University of Edinburgh, 1983).

Brioist, Pascal, 'Hooke et Pepys. Deux espaces-vécus du Londres du XVIIe siècle', in Images et imaginaires de la ville à l'époque moderne, ed. Claude Petitfrère (Tours, 1998), 15-34.

Broadhead, Glenn J., 'Samuel Johnson and the Rhetoric of Conversation', Studies in English Literature, 1500-1900 20, no. 3 (Summer, 1980), 461-74.

Broich, Ulrich, The Eighteenth-century Mock-Heroic Poem, trans. David Henry Wilson (Cambridge, 1990).

Bromwich, David, The Intellectual Life of Edmund Burke: From the Sublime and Beautiful to American Independence (Cambridge, MA, 2014). 
Bryson, Anna, From Courtesy to Civility: Changing Codes of Conduct in Early Modern England (Oxford, 1998).

Burr, Vivien, The Person in Social Psychology (New York, 2002).

Butler, Gerald J., 'Defoe's Moll Flanders vs. Social Illusion', in La Sociabilité en France et en Grande-Bretagne au Siècle des Lumières: Lémergence d'un nouveau modèle de société. Tome 4. Utopie, individu et société: la sociabilité en question, ed. Norbert Col and Allan Ingram (Paris, 2015), 55-71.

_- Love and Reading: An Essay in Applied Psychoanalysis (New York, 1989).

Caine, Barbara, ed., Friendship: A History (London, 2009).

Capdeville, Valérie, L'Age d'or des clubs londoniens (1730-1784) (Paris, 2008).

— - 'Clubbability: A Revolution in London Sociability', Lumen 35 (2016), 63-80.

— - 'The Ambivalent Identity of Eighteenth-century London Clubs as a Prelude to Victorian Clublife, Cahiers victoriens et édouardiens 81 (printemps 2015), https://cve.revues.org/1976.

— - 'Gender at Stake: The Role of Eighteenth-century London Clubs in Shaping a New Model of English Masculinity', Culture, Society E Masculinities 4, no. 1 (Spring 2012), 13-32.

Capdeville, Valérie and Eric Francalanza, eds., La Sociabilité en France et en Grande-Bretagne au siècle des Lumières, vol. 3. Les Espaces de sociabilité (Paris, 2014).

Carr, Rosalind, Gender and Enlightenment Culture in Eighteenth-Century Scotland (Edinburgh, 2014).

Carter, Philip, Men and the Emergence of Polite Society, Britain 166o-180o (London, 2001; New York, 2014).

Charle, Christophe, ed., Le Temps des capitales culturelles XVIIe-XXe siècles (Seyssel, 2009).

Clark, J. C. D., English Society, 1660-1832: Religion, Ideology and Politics during the Ancien Régime (Cambridge, 200o).

Clark, Peter, British Clubs and Societies 1580-180o. The Origins of an Associational World (Oxford, 20oo).

_- Sociability and Urbanity: Clubs and Societies in the Eighteenth-Century City (Leicester, 1986).

- The English Alehouse: A Social History, 1200-183o (London, 1983).

Clayton, Antony, London's Coffee Houses: A Stimulating Story (London, 2003).

Clery, Emma, 'Women, Publicity and the Coffee-House Myth', Women: a Cultural

Review 2, no. 2 (1991), 168-77.

Cochin, Augustin, La Révolution et la libre-pensée, posth. 1924 (Paris, 1955).

Cohen, Michèle, Fashioning Masculinity: National Identity and Language in the Eighteenth Century (London, 1996).

, 'Manliness, Effeminacy and the French: Gender and the Construction of National Character in Eighteenth-Century England', in English Masculinities. 1660-180o, ed. Michèle Cohen and Tim Hitchcock (London and NY, 1999), $44-61$.

Col, Norbert, 'Burke's Target in A Vindication of Natural Society: From Bolingbroke to "this sort of Writers", or an Early Burkean Defense of Church and State, 
1650-1850: Ideas, Æsthetics, and Inquiries in the Early Modern Era 20 (2013), 89-112.

Colley, Linda, 'The Loyal Brotherhood and the Cocoa Tree: the London Organization of the Tory Party, 1727-176o', Historical Journal 20, no. 1 (1977), 77-85.

Cone, Carl B., Burke and the Nature of Politics, 2 vols. (Lexington, 1957 and 1964). Copeland, Thomas W., Edmund Burke: Six Essays (London, 1950).

Cosh, Mary, Edinburgh: the Golden Age (Edinburgh, 2003).

Cossic-Péricarpin, Annick, Bath au XVIIIe siècle. Les fastes d'une cité palladienne (Rennes, 2000).

Cottret, Bernard, Bolingbroke: Exil et écriture au siècle des Lumières. AngleterreFrance (vers 1715-vers 1750), 2 vols. (Paris, 1992).

—_, La Glorieuse Révolution d'Angleterre: 1688, 1988 (Paris, 2013).

Coulton, Richard, “The Darling of the Temple-Coffee-House Club": Science, Sociability and Satire in Early Eighteenth-Century London', Journal for EighteenthCentury Studies 35 (2011), 43-65.

Cowan, Brian, 'Geoffrey Holmes and the Public Sphere: Augustan Historiography from Post-Namierite to the Post-Habermasian', Parliamentary History 28, no. 1 (2009) 166-78.

—, 'News, Biography, and Eighteenth-Century Celebrity', in Oxford Handbooks Online, ed. Thomas Keymer, general ed., Colin Burrow (Oxford, 7 September 2016), doi: 10.1093/oxfordhb/9780199935338.013.132.

- ' 'Public Spaces, Knowledge and Sociability', in The Oxford Handbook of the History of Consumption, ed. Frank Trentmann (Oxford, 2012), 251-66.

- The Social Life of Coffee: The Emergence of the British Coffeehouse (New Haven, CT, 2005).

—_, 'What Was Masculine about the Public Sphere? Gender and the Coffeehouse Milieu in Post-Restoration England', History Workshop Journal, 51 (February 2001), 127-57.

Cressy, David, Literacy and the Social Order: Reading and Writing in Tudor and Stuart England (Cambridge, 1980).

Cruickshanks, Eveline, 'Le XVIIIe siècle: de la Glorieuse Révolution à la Révolution française,', in Histoire des îles Britanniques du XVIe au XVIIIe siècle, ed. Bernard Cottret, Eveline Cruickshanks and Charles Giry-Deloison, trans. Mariette Martin (Paris, 1994), 157-233.

Cust, Lionel, History of the Society of Dilettanti (London, 1898).

$\_$LIIdée du peintre parfait, 1715 (Paris, 1993).

Czennia, Bärbel, 'Floating Communities', in La Sociabilité en France et en GrandeBretagne au Siècle des Lumières : Lémergence d'un nouveau modèle de société. Tome 4. Utopie, individu et société : la sociabilité en question, ed. Norbert Col and Allan Ingram (Paris, 2015), 223-63.

Dachez, Hélène, 'Epistolary sociability: Samuel Richardson and his Readers', in La Sociabilité en France et en Grande-Bretagne au Siècle des Lumières. Tome 5. Sociabilités et esthétique de la marge, ed. Annick Cossic-Péricarpin and Alain Kerhervé (Paris, 2016), 127-52.

Daudin, Guillaume, Commerce et prospérité: la France au XVIIIe siècle (Paris, 2011). 
Davis, Michael T., 'Introduction', in London Corresponding Society, 1792-1799, ed. Michael T. Davis, 6 vols. (London and Brookfield, VT, 2002).

_- "Meet and Sing, and Your Chains Will Drop Off Like Burnt Thread": The Political Songs of Thomas Spence', in Thomas Spence: The Poor Man's Revolutionary, ed. Alastair Bonnett and Keith Armstrong (London, 2014), 109-25.

_ - 'The Mob Club? The London Corresponding Society and the Politics of Civility in the 179os', in Unrespectable Radicals? Popular Politics in the Age of Reform, ed. Paul A. Pickering and Michael T. Davis (Aldershot, 2008), 21-40.

Davis, Michael T., Iain McCalman and Christina Parolin, Newgate in Revolution: An Anthology of Radical Prison Literature in the Age of Revolution (London; New York, 2005).

Davison, Kate, ‘Occasional Politeness and Gentlemen's Laughter in 18th-century England', Historical Journal 57, no. 4 (2014), 921-45.

Deane, Seamus, Foreign Affections: Essays on Edmund Burke (Cork, 2005).

Dozier, Robert R., For King, Constitution and Country: the English Loyalists and the French Revolution (Lexington, 1983).

Dunan-Page, Anne and Beth Lynch, eds., Roger L'Estrange and the Making of Restoration Culture (Aldershot, 2008).

Duthille, Rémy, 'Toasting and the Diffusion of Radical Ideas, 1780-1832', in Radical Voices, Radical Ways: Articulating and Disseminating Radicalism in Seventeenth and Eighteenth-century Britain, ed. Laurent Curelly and Nigel Smith (Manchester, 2016).

— - 'Political Toasting in the Age of Revolutions: Britain, America and France, 1765-180o', in Liberty, Property and Popular Politics: England and Scotland, 1688-1815. Essays in Honour of H. T. Dickinson, ed. Gordon Pentland and Michael Davis (Edinburgh, 2015).

Edwards, Avery, Frederick Louis, Prince of Wales (London, 1947).

Eley, Geoff, 'Nations, Publics, and Political Culture: Placing Habermas in the Nineteenth Century', in Habermas and the Public Sphere, ed. Craig J. Calhoun (Cambridge, MA and London, 1993), 289-339.

Ellis, Markman, 'General Introduction', Eighteenth-Century Coffee-House Culture, 4 vols. (London, 2006), I, xi-xxxi.

- The Coffee-house: A Cultural History (London, 2004).

—, 'The Coffee-women, The Spectator and the Public Sphere in the Early-eighteenth Century', in Women and the Public Sphere, ed. Elizabeth Eger and Charlotte Grant (Cambridge, 2001), 27-52.

Ellis, Markman, Richard Coulton and Matthew Mauger, Empire of Tea (London, 2015).

Epstein, James, "Equality and No King": Sociability and Sedition: the Case of John Frost', in Romantic Sociability: Social Networks and Literary Culture in Britain 1770-1840, ed. Gillian Russell and Clara Tuite (Cambridge, 2002), 43-61.

_- In Practice: Studies in the Language and Culture of Popular Politics in Modern Britain (Stanford, Ca, 2003).

Epstein, James and David Karr, 'Playing at Revolution: British "Jacobin" Performance', The Journal of Modern History, 79 (2007), 495-530. 
Eriksson, Åke, The Tragedy of Liberty: Civic Concern and Disillusionment in James Thomson's Tragic Dramas (Uppsala, 2002).

Everitt, Alan, 'Social Mobility in Early Modern England', Past \& Present 33 (1966), $56-73$.

Featherstone, D., 'Contested Relationalities of Political Activism: The Democratic Spatial Practices of the London Corresponding Society', Cultural Dynamics 22 (2010), 87-104.

- 'The Spatial Politics of the Past Unbound: Transnational Networks and the Making of Political Identities', Global Networks 7 (2007), 430-52.

Fort, Bernadette, ed., Les Salons des 'Mémoires secrets' 1767-1787 (Paris, 1999).

Fraser, Nancy, 'Rethinking the Public Sphere: A Contribution to a Critique of Actually Existing democracy', in Habermas and the Public Sphere, ed. Craig Calhoun (Cambridge, MA, 1992), 109-42.

Fuchs, Michel, Edmund Burke, Ireland and the Fashioning of Self(Oxford, 1996).

Furet, François, Penser la Révolution française (Paris, 1978).

Geikie, Archibald, Annals of the Royal Society Club, the Record of a London Diningclub in the Eighteenth and Nineteenth Centuries (London, 1917).

Gerrard, Christine, Aaron Hill: The Muses' Projector 1685-1750 (Oxford, 2003).

- The Patriot Opposition to Walpole (Oxford, 1994).

Gibbons, Luke, Edmund Burke and Ireland: Aesthetics, Politics, and the Colonial Sublime (Cambridge, 2003).

Gibson-Wood, Carol, Jonathan Richardson, Art Theorist of the Enlightenment (New Haven, CT, 2000).

Gilmartin, Kevin, 'Counter-Revolutionary Culture', in The Cambridge Companion to British Literature of the French Revolution in the 179os, ed. Pamela Clemit (Cambridge, 2011), 129-44.

— Print Politics: The Press and Radical Opposition in Early Nineteenth-Century England, Cambridge Studies in Romanticism 21 (New York, 1996).

—, Writing Against the Revolution: Literary Conservatism in Britain, 1790-1832 (Cambridge, 2009).

Glover, Katharine, Elite Women and Polite Society in Eighteenth-Century Scotland (Woodbridge, 2011).

Gluckman, Max, 'Gossip and Scandal', Current Anthropology 4, no. 3 (1963), 307-16.

Goldie, Mark, Tim Harris and Paul Seaward, eds., The Politics of Religion in Restoration England (Oxford, 1990).

Goodman, Dena, The Republic of Letters: A Cultural History of the French Enlightenment (Ithaca, NY, 1994).

Goodwin, Albert, The Friends of Liberty: The English Democratic Movement in the Age of the French Revolution (London, 1979).

Green, Georgina, The Majesty of The People: Popular Sovereignty and the Role of the Writer in the 1790s (Oxford, 2014).

Green, Lawrence D., 'French Letters and English Anxiety in the Seventeenth Century', Huntington Library Quarterly 66, no. 3/4 (2003) 263-274.

Greig, Hannah, The Beau Monde: Fashionable Society in Georgian London (Oxford, 2013). 
Guichard, Charlotte, 'L'Amateur dans la polémique sur la critique d'art au XVIIIe siècle', in Penser l'art dans la seconde moitié du XVIIIe siècle: théorie, critique, philosophie, histoire, ed. Carl Magnusson and Christian Michel (Paris, 2013), $113-26$.

— L Les Amateurs d'art à Paris au XVIIIe siècle (Seyssel, 2008).

Habermas, Jürgen, 'The Public Sphere: An Encyclopedia Article', New German Critique 3 (1974), 49-55.

— - The Structural Transformation of the Bourgeois Public Sphere: An Inquiry into a Category of Bourgeois Society, trans. Thomas Burger and Frederick Lawrence (Cambridge, 1989; Cambridge, MA, 1991).

Harris, Tim, Politics under the Later Stuarts: Party Conflict in a Divided Society, 1660-1715 (London, 1993).

Haslett, Moyra, 'Bluestocking Feminism Revisited: the Satirical Figure of the Bluestocking', Women's Writing 17 (2010), 432-51.

Heller, Deborah, 'Bluestocking Salons and the Public Sphere, Eighteenth-Century Life 22 (1998), 59-82.

Herbert, Amanda E., Female Alliances: Gender, Identity, and Friendship in Early Modern Britain (New Haven, 2014).

Hirst, Derek, 'Locating the 1650 in England's Seventeenth Century', History 81 (1996), 359-83.

Holmes, Geoffrey, Politics, Religion, and Society in England, 1679-1742 (London, 1986).

—, British Politics in the Age of Anne, revised edition (London, 1987).

Hoock, Holger, The King's Artists: The Royal Academy of Arts and the Politics of British Culture 1760-1840 (Oxford, 2003).

Hoppit, Julian, Britain's Political Economies: Parliament and Economic Life, 16601800 (Cambridge, 2017).

Hornbeak, Katherine Gee, The Complete Letter Writer in English 1568-18oo. Smith College Studies in Modern Languages 15, no. 3/4 (1934).

Hutchison, Sydney C., The History of the Royal Academy 1768-1786 (London, 1986).

Innes, Joanna, 'Jonathan Clark, Social History and England's " Ancien Régime ", Past E Present 115 (1987), 165-200.

Irving, William, The Providence of Wit in the English Letter Writers (Durham, NC, 1955).

Jacobs, Eva, Theatre in Focus: Voltaire and Tragedy (Cambridge, 1987).

Jones, E. M. and M. E. Falkus, 'Urban Improvement and the English Economy in the Seventeenth and Eighteenth Centuries', in The Eighteenth-Century Town 1688-1820, ed. Peter Borsay (London and New York, 1990), 116-58.

Jones, Emrys D., Friendship and Allegiance in Eighteenth-Century Literature: The Politics of Private Virtue in the Age of Walpole (Basingstoke, 2013).

_ - 'Royal Ruptures: Caroline of Ansbach and the Politics of Illness in the 173os', Medical Humanities 37 (2011), 13-17.

Jones, Richard, Tobias Smollett in the Enlightenment (Bucknell, 2011).

Keen, Maurice, Chivalry (New Haven, CT, 1984).

Kenyon, John P., The Stuart Constitution: Documents and Commentary (Cambridge, 1966). 
Klancher, Jon, The Making of English Reading Audiences, 1790-1832 (Madison, WI and London, 1987).

Klein, Lawrence E., 'Coffeehouse Civility, 166o-1714: An Aspect of Post-Courtly Culture in England', Huntington Library Quarterly 59, no. 1 (1996), 30-52.

— , 'Liberty, Manners and Politeness in Early Eighteenth-Century England', Historical Journal 32, no. 3 (1989), 583-605.

— , 'Politeness and the Interpretation of the British Eighteenth Century', Historical Journal 45, no. 4 (December 2002), 869-98.

— , 'Politeness for Plebes. Consumption and Social Identity in Early Eighteenthcentury England', in The Consumption of Culture, ed. John Brewer and Ann Bermingham (London, 1997), 262-82.

—, Shaftesbury and the Culture of Politeness: Moral Discourse and Cultural Politics in Early Eighteenth-Century England (Cambridge, 1994).

— , 'The Figure of France: The Politics of Sociability in England, 166o-1715', Yale French Studies 92 (1997), 30-45.

Knapp, Lewis Mansfield, Tobias Smollett, Doctor of Man and Manners (1949; London, 1963).

Knights, Mark, Representation and Misrepresentation in Later Stuart Britain: Partisanship and Political Culture (Oxford, 2005).

Kramnick, Isaac, The Rage of Edmund Burke: Portrait of an Ambivalent Conservative (New York, 1977).

Langford, Paul, Public Life and the Propertied Englishman: 1689-1798 (Oxford, 1991).

Lawlor, Clark, Consumption and Literature: The Making of a Romantic Disease (London, 2006).

Le Goff, Jacques, Histoire et mémoire (Paris, 1988).

Lepan, Géraldine, 'Politesse et sociabilité selon Rousseau', in La Sociabilité en France et en Grande-Bretagne au Siècle des Lumières : L'émergence d'un nouveau modèle de société. Tome 4. Utopie, individu et société : la sociabilité en question, ed. Norbert Col and Allan Ingram (Paris, 2015), 167-96.

Lichtenstein, Jacqueline and Christian Michel, eds., Conférences de l'Académie royale de peinture et de sculpture (Paris, 2006-15).

Lieberman, Max, 'A New Approach to the Knighting Ritual', Speculum 9o, no. 2 (2015), 391-423.

Lilti, Antoine, The World of the Salons: Sociability and Worldliness in Eighteenth-

Century Paris, trans. Lydia Cochrane (Oxford, 2015).

Lock, Frederick Peter, Edmund Burke, 2 vols., I, 1998 (Oxford, 2008); II, 2006 (Oxford, 2009).

Loftis, John, The Politics of Drama in Augustan England (Oxford, 1963).

Lord, Walter Frewen, 'The Development of Political Parties during the Reign of Queen Anne', Transactions of the Royal Historical Society 14 (1900), 69-121.

Lottes, Günther, Politische Aufklärung und Plebejisches Publikum: Zur Theorie und Praxis des Englischen Radikalismus im Späten 18. Jahrhundert (Munich and Vienna, 1979). 
Lottes, Günther, 'Radicalism, Revolution and Political Culture: An Anglo-French Comparison', in The French Revolution and British Popular Politics, ed. Mark Philp (Cambridge, 1991), 78-98.

Lyotard, Jean-François, The Postmodern Condition: A Report on Knowledge, trans. Geoff Bennington and Brian Massumi (Minneapolis, 1997).

Manogue, Ralph A. 'The Plight of James Ridgway, London Bookseller and Publisher, and the Newgate Radicals, 1792-1797, Wordsworth Circle 27 (1996), 158-66.

McCalman, Iain, Radical Underworld: Prophets, Revolutionaries and Pornographers in London, 1795-184o (Cambridge, 1988; Oxford, 1998).

Macaulay, Thomas Babington, History of England from the Accession of James II, 5 vols. (London, 1848).

McElroy, Davis D., Scotland's Age of Improvement: A Survey of Eighteenth Century Literary Clubs and Societies (Washington, 1969).

MacFaul, Tom, Male Friendship in Shakespeare and his Contemporaries (Cambridge, 2007).

McGirr, Elaine, Heroic Mode and Political Crisis, 1660-1745 (Newark, 2009).

MacGuire, Nancy Klein, Regicide and Restoration: English Tragicomedy, 1660-1681 (Cambridge, 1992).

McKellar, Elizabeth, The Birth of Modern London (Manchester, 1999).

McKendrick, Neil, John Brewer and J. H. Plumb, eds., The Birth of a Consumer Society. The Commercialization of Eighteenth-Century England (London, 1992).

Mansfield, Harvey C. Jr., Statesmanship and Party Government: A Study of Burke and Bolingbroke (Chicago, 1965).

Martin, Ann, 'Tea Tables Overturned: Rituals of Power and Place in Colonial America', in Furnishing the Eighteenth Century: What Furniture can tell us about the European and American Past, ed. Dena Goodman and Kathryn Norberg (London, 2007), 169-81.

Martz, Louis L., The Later Career of Tobias Smollett (New Haven, CT, 1942).

Mee, Jon, Conversable Worlds: Literature, Contention, and Community 1762 to 1830 (Oxford, 2011).

—, Print, Publicity, and Popular Radicalism in the 179os: The Laurel of Liberty (Cambridge, 2016).

- 'Thomas Spence and the London Corresponding Society, 1792-1795', in Thomas Spence: The Poor Man's Revolutionary, ed. Alastair Bonnett and Keith Armstrong (London, 2014), 53-63.

Mitchell, L. G., Charles James Fox (Oxford, 1992). , ed., The French Revolution: 1790-94, vol. VIII of The Writings and Speeches of Edmund Burke, general editor Paul Langford (Oxford, 1989).

Moran, Mary Catherine, "The Commerce of the Sexes": Gender and the Social Sphere on Scottish Enlightenment Accounts of Civil Society', in Paradoxes of Civil Society: New Perspectives on Modern German and British History, ed. Frank Trentmann, revised second edition (New York and Oxford, 2003), 61-84.

Morieux, Renaud, Une mer pour deux royaumes. La Manche, frontière francoanglaise XVIIe-XVIIIe siècles (Rennes, 2008).

Neufield, Matthew, The Civil Wars After 166o: Public Remembering in Late Stuart England (Woodbridge, 2013). 
Newman, Ian David, 'Tavern Talk Literature, Politics and Conviviality' (Unpublished Ph.D. Diss., University of California, Los Angeles, 2013).

Newman, A. N., 'Communication: The Political Patronage of Frederick Lewis, Prince of Wales', Historical Journal 1, no. 1 (1958), 68-75.

Norman, Larry F., 'Modern Identity and the Sociable Self in the Late Seventeenth Century', Nottingham French Studies 47, no. 3 (Autumn 2008), 34-44.

O'Brien, Conor Cruise, The Great Melody: A Thematic Biography and Commented Anthology of Edmund Burke (London, 1992).

O'Gorman, Frank, 'Campaign Rituals and Ceremonies: The Social Meaning of Elections in England', Past and Present 135 (1992), 79-115.

Parker, G. F., Johnson's Shakespeare (Oxford, 1989).

Pears, Ian, The Discovery of Painting: The Growth of Interest in the Arts in England, 1680-1768 (New Haven, CT, 1988).

Pearson, Roger, Voltaire Almighty: A Life in Pursuit of Freedom (London, 2005).

Peck, Linda Levy, Consuming Splendour: Society and Culture in Seventeenth-Century England (Cambridge, 2005).

Peltonen, Markku, 'Politeness and Whiggism, 1688-1732', Historical Journal 48, no. 2 (June 2005), 391-414.

—, The Duel in Early Modern England: Civility, Politeness and Honour (Cambridge, 2003).

Perkins, Pam, Women Writers and the Edinburgh Enlightenment (Amsterdam, 2010).

_, "A Constellation of Scottish Genius": Networks of Exchange in Late 18th- and Early 19th-Century Edinburgh', Lumen 34 (2015), 39-54.

Pevsner, Nikolaus, Les Académies d'art, trans. Jean-Jacques Bretou (Paris, 1990).

Philp, Mark, 'The Fragmented Ideology of Reform', in The French Revolution and British Popular Politics, ed. Mark Philp (Cambridge, 1991), 50-77.

__, 'Vulgar Conservatism, 1792-3,' English Historical Review 110 (1995), 42-69.

Pickering, Paul A. and Michael T. Davis, Unrespectable Radicals? Popular Politics in the Age of Reform (Aldershot, England and Burlington, VT, 2008).

Pincus, Steven, "Coffee Politicians Does Create": Coffeehouses and Restoration Political Culture,'Journal of Modern History 67, no. 4 (December 1995), 807-34.

Plassart, Anna, The Scottish Enlightenment and the French Revolution (Cambridge, 2015).

Plumb, John H., The Origins of Political Stability, England 1675-1725 (Boston, 1967).

Pocock, John G. A., The Ancient Constitution and the Feudal Law: A Study of English historical Thought in the Seventeenth Century. A Reissue with a Retrospect, 1987 (Cambridge, 1990).

- 'The Political Economy of Burke's Analysis of the French Revolution', 1982, Virtue, Commerce, and History, 1985 (Cambridge, 1991), 193-212.

- Virtue, Commerce, and History: Essays on Political Thought and History, Chiefly in the Eighteenth Century (Cambridge, 1976).

Porset, Charles, Les Philalèthes et les Convents de Paris, Une politique de la folie (Paris, 1996). 
Porset, Charles and Marie-Cécile Révauger, eds., Le Monde maçonnique des Lumières (Europe/the Americas \& Colonies). Dictionnaire prosopographique (Paris, 2013).

Porter, Roy, English Society in the Eighteenth Century, second edition (Harmondsworth, 1990).

Price, Richard, British Society 1680-1880, Dynamism, Containment and Change (Cambridge, 1999).

Rancière, Jacques, Les Mots de l'histoire: Essai de politique du savoir (Paris, 1992).

Rasmussen, Steen Eiler, London, the Unique City (London, 1937).

Rendall, Jane 'Bluestockings and Reviewers: Gender, Power and Culture in Britain, c. 1800-1830', Nineteenth-Century Contexts 26 (2004), 355-74.

_ - "Women that would plague me with rational conversation": Aspiring Women and Scottish Whigs c. 1790-1830', in Women, Gender and Enlightenment, ed. Sarah Knott and Barbara Taylor (Basingstoke, 2005), 326-47.

—-, 'Gender, Philanthropy and Civic Identities in Edinburgh, 1795-1830', in The Routledge History Handbook of Gender and the Urban Experience, ed. Deborah Simonton (London, 2017), 213-14.

Riley, Margaret, 'The Club at the Temple Coffee House Revisited', Archives of Natural History 33, no. 1 (April 2006), 90-100.

Robelin, Roger de, 'Die Freimaurerei in Schweden im 18 Jahrhundert,' Gold und Himmelblau. Die Freimaurerei, Zeitloses Ideal (Abo, 1993).

Roper, Michael and John Tosh, 'Hegemonic Masculinity and the History of Gender', in Masculinities in Politics and War: Gendering Modern History, ed. S. Dudink, K. Hagemann and John Tosh (Manchester, 2004), 41-58.

Russell, Gillian, Women, Sociability and Theatre in Georgian London (Cambridge, 2007).

Russell, Gillian and Clara Tuite, eds., Romantic Sociability: Social Networks and Literary Culture in Britain 1770-1840 (Cambridge, 2002).

Saul, Nigel, For Honour and Fame: Chivalry in England, 1066-150o (London, 2011).

Schellenberg, Betty, Literary Coteries and the Making of Modern Print Culture, 1740-1790 (Cambridge, 2016).

Schmid, Susanne, British Literary Salons of the Late Eighteenth and Early Nineteenth Centuries (Basingstoke and New York, 2013).

Schneewind, J. B., Essays on the History of Moral Philosophy (Oxford, 2009).

Scrivener, Michael Henry, Seditious Allegories: John Thelwall and Jacobin Writing

(University Park, PA, 2001).

Shepard, Alexandra, Meanings of Manhood in Early Modern England (Oxford, 2006).

Siegel, Jerrold, The Idea of the Self. Thought and Experience in Western Europe since the Seventeenth Century (Cambridge, 2005).

Simmel, Georg, Soziologie (Berlin, 1908).

—, 'The Sociology of Sociability', in Simmel on Culture. Selected Writings, ed. David Frisby and Mike Featherstone (London, 1997), 120-9.

Sirota, Brent S., The Christian Monitors: The Church of England and the Age of Benevolence, 1680-1730 (New Haven, CT, 2014). 
Smith, E. A., Whig Principles and Party Politics: Earl Fitzwilliam and the Whig Party, 1748-1833 (Manchester, 1975).

Spacks, Patricia Meyer, Gossip (New York, 1985).

Spedding, Patrick, A Bibliography of Eliza Haywood (London, 2004).

Speier, Hans, 'Historical Development of Public Opinion', American Journal of Sociology 55, no. 4 (January 1950), 376-88.

Stephen, Leslie, English Literature and Society in the Eighteenth Century (London, 1904).

Stevenson, Christine, The City and the King: Architecture and Politics in Restoration (London and New Haven, 2013).

Stone, Lawrence, 'The Residential Development of the West End of London in the Seventeenth Century', in After the Reformation, ed. B. Malament (Manchester, 1980), 167-212.

Strohm, Reinhard, Essays on Handel and Italian Opera (Cambridge, 1985).

Strosetzki, Christoph and Bernard Bray, Art de la lettre, art de la conversation à l'époque classique en France (Paris, 1995).

Talmon, Jacob Laib, The Origins of Totalitarian Democracy (London, 1952).

Tapsell, Grant, ed., The Later Stuart Church, 1660-1714 (Manchester, 2012).

Taylor, Brandon, Art for the Nation: Exhibitions and the London Public 1741-2001 (New Brunswick, NJ, 1999).

Taylor, P. J., M. Hoyler and D. M. Evans, 'A Geohistorical Study of "The Rise of Modern Science": Mapping Scientific Practice through Urban Networks, 15001900', Minerva 46, no. 4 (2008), 391-410.

Thale, Mary, ed., Selections from the Papers of the London Corresponding Society, 1792-1799 (Cambridge and New York, 1983).

Thomson, Ann, Simon Burrows and Edmond Dziembowski, eds., with Sophie Audidière, Cultural Transfers: France and Britain in the Long Eighteenth Century (Oxford, 2010).

Thompson, E. P., The Making of the English Working Class (Harmondsworth, 1980).

Thornton, Peter and Maurice Tomlin, The Furnishing and Decoration of Ham House (London, 1980).

Todd, Janet, Mary Wollstonecraft: A Revolutionary Life (London, 200o).

Turberville, Arthur S., Johnson's England, an Account of the Life and Manners of his Age, 2 vols. (Oxford, 1933, 1965).

Turner, James Grantham, Libertines and Radicals in Early Modern London: Sexual-

ity, Politics and Literary Culture, 1630-1685 (Cambridge, 2002).

Van Damme, Stéphane, Descartes. Essai d'histoire culturelle d'une grandeur philosophique (XVIIe-XXe siècle) (Paris, 2002).

Vickery, Amanda, Behind Closed Doors: At Home in Georgian England (New Haven, CT, 2009).

_ , 'Golden Age to Separate Spheres? A Review of the Categories and Chronology of English Women's History', Historical Journal 36, no. 2 (June 1993), 383-414.

—, The Gentleman's Daughter. Women's Lives in Georgian England (New Haven, $\mathrm{CT}, 2003)$.

Vivian, Frances, A Life of Frederick, Prince of Wales, 1707-1751, ed. Roger White (Lewiston, 2006). 
Wahrman, Dror, The Making of the Modern Self. Identity and Culture in EighteenthCentury England (New Haven, CT and London, 2004).

Waith, Eugene M., Ideas of Greatness: Heroic Drama in England (London, 1971).

Walker, Matthew F., 'The Limits of Collaboration: Robert Hooke, Christopher Wren and the Designing of the Monument to the Great Fire of London', Notes \& Records of the Royal Society 65 (2011), 121-43.

Walker, Sue, 'The Manners of the Page: Prescription and Practice in the Visual Organization of Correspondence', Huntington Library Quarterly 66, no. 3/4 (2003), 307-29.

Wall, Cynthia, The Literary and Cultural Spaces of Restoration (Cambridge, 1998).

Warner, Pamela J., 'Connoisseur vs Amateur: A Debate over Taste and Authority in Late Eighteenth-Century Paris', in Penser l'art dans la seconde moitié du XVIIIe siècle: théorie, critique, philosophie, histoire, ed. Carl Magnusson and Christian Michel (Paris, 2013), 177-200.

Weatherill, Lorna, Consumer Behaviour and Material Culture in Britain, 16601760 (London, 1996).

Weinstein, Benjamin, 'Popular Constitutionalism and the London Corresponding Society', Albion: A Quarterly Journal Concerned with British Studies 34 (2002), 37-57.

Werkmeister, Lucyle, The London Daily Press, 1772-1792 (Lincoln, NE, 1963).

Whyman, Susan, The Pen and the People: English Letter Writers 1660-180o (Oxford, 2009).

Withington, Phil, 'Company and Sociability in Early Modern England', Social History 32, no. 3 (2007), 291-307.

- Society in Early Modern England: The Vernacular Origins of Some Powerful Ideas (Cambridge, 2010).

Zevi, Bruno, Saper Vedere la Città (Turin, 1960). 